\title{
Differential preservation of vertebrates in Southeast Asian caves
}

\author{
Julien Louys ${ }^{1,8^{*}}$, Shimona Kealy ${ }^{1}$, Sue O'Connor ${ }^{1}$, Gilbert J. Price ${ }^{2}$, Stuart Hawkins ${ }^{1}$, \\ Ken Aplin ${ }^{3}$, Yan Rizal ${ }^{4}$, Jahdi Zaim ${ }^{4}$, Mahirta ${ }^{5}$, Daud A. Tanudirjo ${ }^{5}$, Wahyu Dwijo Santoso ${ }^{4}$, \\ Ati Rati Hidayah ${ }^{5}$, Agus Trihascaryo ${ }^{4}$, Rachel Wood ${ }^{6}$, Joseph Bevitt ${ }^{7}$, and Tara Clark ${ }^{2,8}$ \\ ${ }^{1}$ ANU College of Asia and the Pacific, Australian National University, Canberra ACT 0200, Australia \\ ${ }^{2}$ School of Earth and Environmental Sciences, University of Queensland, St Lucia QLD 4072, Brisbane, Australia \\ ${ }^{3}$ Division of Mammals, National Museum of Natural History, Smithsonian Institution, Washington, D.C., DC 20560, USA \\ ${ }^{4}$ Geology Study Program, Institut Teknologi Bandung, Jawa Barat 40132, Indonesia \\ ${ }^{5}$ Jurusan Arkeologi, Fakultas Ilmu Budaya, Universitas Gadjah Mada, Yogyakarta 55281, Indonesia \\ ${ }^{6}$ Research School of Earth Sciences, Australian National University, Canberra ACT 0200, Australia \\ ${ }^{7}$ Australian Centre for Neutron Scattering, Australian Nuclear Science and Technology Organisation, Kirrawee DC NSW 2232, Australia \\ ${ }^{8}$ Australian Research Centre for Human Evolution, Griffith University, Nathan QLD 4111, Australia
}

\begin{abstract}
Caves have been an important source of vertebrate fossils for much of Southeast Asia, particularly for the Quaternary. Despite this importance, the mechanisms by which vertebrate remains accumulate and preserve in Southeast Asian caves has never been systematically reviewed or examined. Here, we present the results of three years of cave surveys in Indonesia and Timor-Leste, describing cave systems and their attendant vertebrate accumulations in diverse geological, biogeographical, and environmental settings. While each cave system is unique, we find that the accumulation and preservation of vertebrate remains are highly dependent on local geology and environment. These factors notwithstanding, we find the dominant factor responsible for faunal deposition is the presence or absence of biological accumulating agents, a factor directly dictated by biogeographical history. In small, isolated, volcanic islands, the only significant accumulation occurs in archaeological settings, thereby limiting our understanding of the palaeontology of those islands prior to human arrival. In karstic landscapes on both oceanic and continental islands, our understanding of the longterm preservation of vertebrates is still in its infancy. The formation processes of vertebratebearing breccias, their taphonomic histories, and the criteria used to determine whether these represent syngenetic or multiple deposits remain critically understudied. The latter in particular has important implications for arguments on how breccia deposits from the region should be analysed and interpreted when reconstructing palaeoenvironments.
\end{abstract}

Keywords: $\quad$ Sumatra, Wallacea, geoarchaeology, taphonomy, palaeontology

Received 2 May 2017; Revised 30 July 2017; Accepted 10 August 2017

Citation: $\quad$ Louys J., Kealy S., O’Connor S., Price G.J., Hawkins S., Aplin K., Rizal Y., Zaim J., Mahirta, Tanudirjo D.A., Santoso W.D., Hidayah A.R., Trihascaryo A., Wood R., Bevitt J. and Clark T., 2017. Differential preservation of vertebrates in Southeast Asian caves. International Journal of Speleology, 46 (3), 379-408. Tampa, FL (USA) ISSN 0392-6672

https://doi.org/10.5038/1827-806X.46.3.2131

\section{INTRODUCTION}

Caves are renowned amongst palaeontologists and archaeologists for their potential to preserve vertebrate remains (e.g., Simms, 1994; Price et al., 2009a; Fairchild \& Baker, 2012; McFarlane, 2013; O'Connor et al., 2016). The unique environmental and geological conditions present in caves provides a focal point on the landscape for the accumulation of animal remains, and a physical means by which those remains might increase in number and subsequently undergo long-term preservation (Simms, 1994; Price et al., 2009b; Fairchild \& Baker, 2012; McFarlane, 2013). Caves have long been recognised as a potential source of fossil vertebrate remains in Southeast Asia (Wallace, 1864), and over the last 150 years they have produced some of the most important deposits for understanding not only mammalian evolution in general, but also the origins and behavioural ecology of hominins (e.g., Dubois, 1891; Morwood et al., 2004; Liu et al., 2010, Mijares et al., 2010; O'Connor et al., 2011; Demeter et al., 2012; Barker, 2013; Morley, 2016). 
Vertebrate remains can accumulate in caves via different processes that can be classified into three categories (Simms, 1994): biotic autochthonous, biotic allochthonous and abiotic allocthonous processes. Biotic autochthonous processes are those resulting from cavernicolous vertebrates (animals that spend all or most of their time in caves). Biotic allochthonous accumulations have remains introduced into the cave by the actions of some biological agent, including predators such as owls and terrestrial carnivores. An important subset of this type of accumulation is represented by archaeological deposits. Finally, abiotic allochthonous deposits are those where vertebrate remains are introduced into the cave environment by physical processes, mostly through natural pit traps and flooding. Once vertebrate remains are introduced into a cave, they can be subjected to further taphonomic processes which can enrich and/ or destroy them. Water movement within a cave system can erode accumulations, particularly during flood events, destroying bones through physical damage resulting from transportation or can carry the bones out of the cave system. Conversely, water movement through passages can have the opposite effect, causing accumulation of deposits at blockages in passages, sediment traps, or in stream placers (Simms, 1994; Duringer et al., 2012). Long-term preservation of fossils within a cave requires lithification, usually from the movement of carbonate rich waters through the deposits - cementing bone-bearing breccias - or capping and hence protecting unconsolidated sediments through the development of overlying flowstones.

Despite the importance of caves as reservoirs for fossils, and their seeming ubiquity in the published palaeontological record, especially for the Pleistocene, the preservation of vertebrate remains and their subsequent discovery and study is unlikely. In one of only a few studies examining this issue, McFarlane (2013) suggested that only $3.8 \%$ of Jamaican caves produced "a publishable vertebrate record". This figure was similar to that of Devon, England, where McFarlane (2013) suggested only some $4.4 \%$ of caves yielded similar Pleistocene-aged deposits. Although specific numbers weren't provided, these figures correspond surprisingly well with survey results reported by Duringer et al. (2012), who suggested only half a dozen caves out of 200 (or $~ 3 \%$ ) investigated in Vietnam and Laos produced fossil deposits worthy of scientific investigation.

Cave deposits containing fossil vertebrates are therefore rare, but for Southeast Asia they have been instrumental to the development of a cohesive understanding of the biogeographic and palaeoenvironmental history of the region (e.g., Bacon et al., 2004, 2006, 2008, 2015; Louys \& Meijaard, 2010; Duringer et al., 2012; Zeiton et al., 2015, 2016). Nevertheless, and despite an increased interest in Southeast Asia's Pleistocene fossil records over the last few decades, the majority of these vertebrate fossil studies have focused on continental Southeast Asia, particularly southern China, Vietnam, Laos, Thailand and Malaysia (but see Glover (1979) for Sulawesi and Westaway et al. (2009) and Gagan et al.
(2015) for examples from Flores). Limited exploration and documentation of caves in Island Southeast Asia means we know very little about the fossil record, and thus palaeontological history, of both large and small islands in this biodiverse region.

In an effort to examine the factors responsible for preservation of vertebrate remains in Southeast Asian caves, and determine if any commonalities exist that may aid in future exploration, we present the results of surveys of caves on islands of various sizes, degrees of isolation, and differing geological and biogeographical histories (Fig. 1). Islands surveyed include the Talaud Islands (small, isolated, some limestone), Sangihe (small, isolated, volcanic), Alor (small, somewhat isolated, limestone and volcanic), Pantar (small, somewhat isolated, volcanic), Timor (medium, somewhat isolated, complex geology), and Sumatra (large, connected, complex geology). We examine the factors that contribute to the preservation or absence of vertebrate remains in caves in this region, with particular emphasis on the effects of local geology, chronology, and taphonomy. Finally, we assess the implications of these biases with respect to understanding the evolutionary history of vertebrates in Southeast Asia.

\section{Geological setting}

\section{Talaud and Sangihe}

The Talaud Islands, consisting of three major islands and several smaller ones, were formed from uplifted Miocene strata as a result of the subduction of the Snellius-Halmahera block under the Sangihe arc during the Plio-Pleistocene (Moore et al., 1981). The Talaud Island block reached sea level during the Pleistocene, at which point coral reefs began to form. Five major rock units have been identified for the islands, consisting of mid-Miocene to Pleistocene marine sediments, volcanic rocks, mélanges, ophiolites, and coralline limestone (Moore et al., 1981). The limestones are predominately found on the coast and many are today experiencing active uplift (Fig. 2). They can be found at elevations of up to $500 \mathrm{~m}$ (Moore et al., 1981), attesting to the speed and magnitude of this uplift. Some minor tilting of the limestone has occurred, but the beds are otherwise undeformed. The island of Sangihe is one of several oceanic islands forming part of the Sangihe volcanic arc. These were formed from volcanoes resulting from the collision between the Sangihe and Halmahera arcs. Sangihe Island has one active andesitic volcano, Awu, situated in the north of the island, with the southern end of the island comprised of dissected volcanic centres (Morrice et al., 1983). The Sangihe arc volcanism probably began sometime around the mid-Miocene (Hall, 2002); however Sangihe Island, like the other currently active volcanoes in the Sangihe arc, is Quaternary in age (Morrice et al., 1983). Unlike Talaud, very few coral reefs are present around the shoreline of Sangihe Island.

\section{Alor and Pantar}

Alor and Pantar belong to the Banda Volcanic Arc, the ring of volcanic islands resulting from 


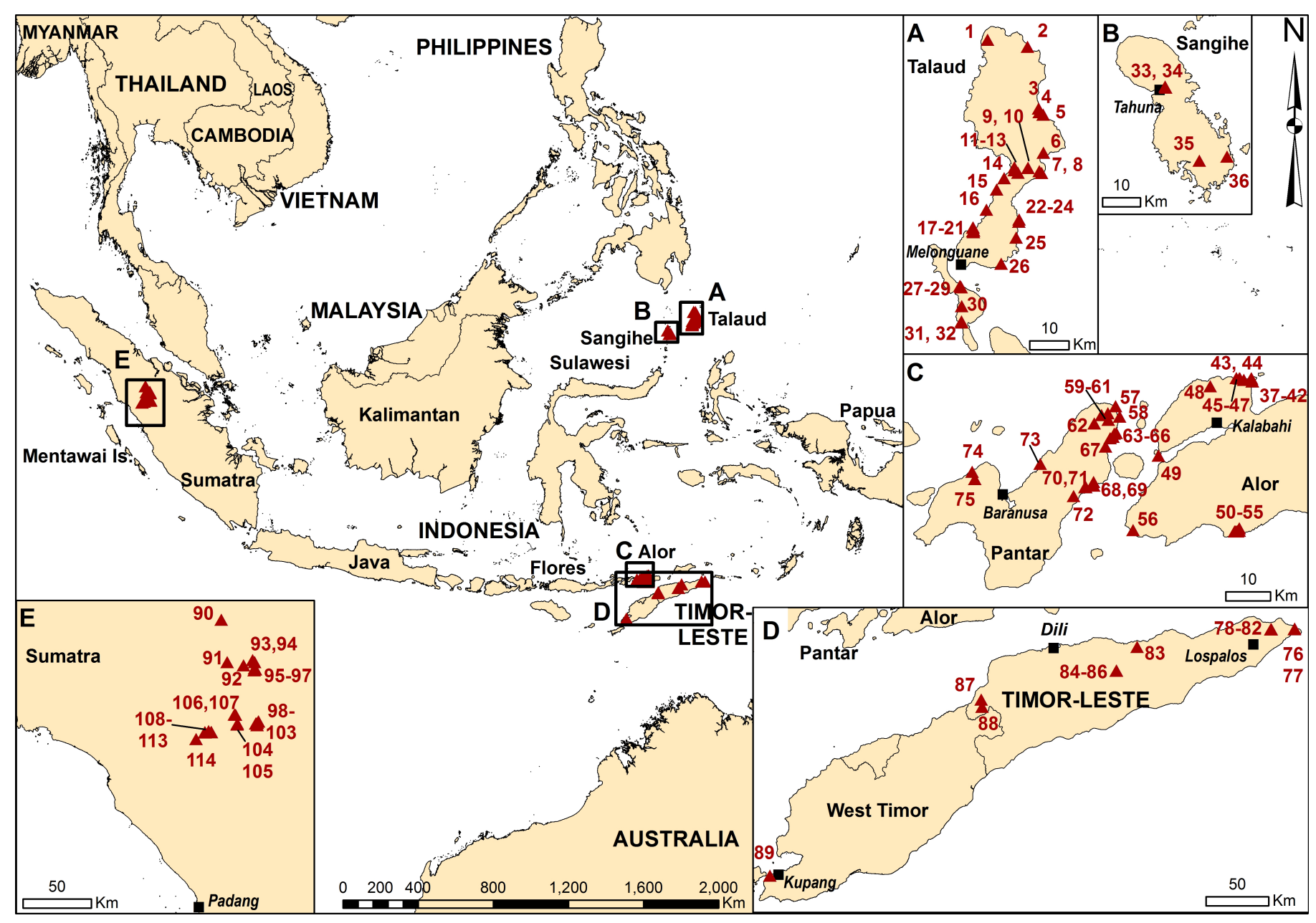

Fig. 1. Map showing cave localities. Numbers refer to caves listed in Table 1.

the collision of the Australian continental margin with the Arc, beginning sometime in the Pliocene (Hutchinson, 2005). The volcanic arc is inactive from Alor, through Wetar and Romang as a result of the arrival of the Australian continental lithosphere at the Sunda Trench (Hutchinson, 1989). Volcanic activity on these islands ceased by about 2-3 Ma (Abbott \& Chamalaun, 1981), and isostatic rebound of the Australian continent following on from this produced significant regional uplift (Hutchinson, 2005). West of Alor, from the island of Pantar to eastern Flores, the Australian continental lithosphere has not yet arrived and volcanic activity remains high. Pantar has one active volcano situated at the southwestern end of the island. The dominant geology on Alor is Pliocene lavas and volcanic breccias. These together with much younger outcropping volcanics characterise Pantar. Rapid uplift of the eastern part of the arc, probably initiated in the early to mid-Pleistocene, has resulted in limestone terraces being found at up to $700 \mathrm{~m}$ in altitude on the Kabola Peninsula, north-western Alor (Hantaro et al., 1994). Uplift rates in this part of Alor were estimated to be in the order of 1.0-1.2 mm/yr (Hantaro et al., 1994). West of Alor, limestone terraces do not appear to have reached quite such high elevations (van Bemmelen, 1949).

\section{Timor}

The island of Timor is the uplifted accretionary complex resulting from the active collision of the Banda volcanic arc with the Australian continental margin at the end of the Miocene (Harris, 1991). Three major phases of orogenesis have been identified (Hutchinson, 2005). The first, an accretionary phase, occurred during the transition between subduction and collision and resulted in frontal accretion of Cretaceous to Pliocene bathyal sediments in a thickening wedge (Hamilton, 1979). Continued collision of the continental slope resulted in shortening and uplift of the wedge as alpine-thrust sheets (Harris, 1991). Following cessation of subduction, isostatic rebound along steep faults resulted in further uplift of the Timor micro-continent (Chamalaun \& Grady, 1978). The first emergence of Timor as an island is suggested to be shortly before 4.45 Ma (Nguyen et al., 2013); however benthic faunas from the Viqueque Sequence indicate that Timor-Leste itself wasn't emergent until sometime after 3.35 to $1.88 \mathrm{Ma}$ (Tate et al., 2014), which correlates with pollen data that suggests the development of Timor as a 'high' island after 3.1 Ma (Nguyen et al., 2013). Emergent coral terraces along $180 \mathrm{~km}$ of the north and eastern-most coast of Timor-Leste at a peak of ca. 1,000 m elevation speaks to considerable Quaternary uplift for at least 150,000 years; although the exact mechanisms of uplift remain unknown, it may be attributed to active crustal shortening (Cox, 2009). The pattern of tectonic uplift is not homogenous from east to west: from Dili to Subau little to no surface uplift is evident, however an abrupt increase is observed between Subau and Manatuto, and uplift continues to be high but variable between Manatuto and Lautem (Cox, 2009). 


\section{Sumatra}

Sumatra forms part of the continental Sundaland, in turn formed from several micro-continents that had rifted from Gondwanaland (Hutchinson, 1989, 2005). Sumatra is largely comprised of the CarboniferousPermian Sinoburmalaya Block which is conformably overlain by limestones of Upper Permian to Triassic age (Hutchinson, 2005). West of this block lies the West Sumatran Carboniferous-Permian block, characterized by Early Permian volcanism, fusulinid limestones and early Cathaysian Jambi flora (Hutchinson, 1993). Western Sumatra is characterised by a Cenozoic volcanic arc resulting from the collision of the Asian and Indo-Australian plates. The fore-arc basin produced from this collision is a strongly subsiding trough bounded in the west by the elevating continental Sundaland margin, with up to $4 \mathrm{~km}$ of Miocene to recent strata transgressing over the Palaeogeneaged continental margin that was uplifted in the Late Oligocene (Hutchinson, 1989). Following this initial uplift, a period of subsidence and sedimentary deposition followed, until approximately $20 \mathrm{Ma}$ when a major upthrust initiated another period of orogeny accompanied by significant volcanic activity (Whitten, 2000). A final period of Pliocene and Pleistocene mountain building is associated with the formation of Quaternary volcanoes along the Barisan Range.

\section{Biogeographical setting}

\section{Talaud and Sangihe}

The Talaud-Sangihe archipelago is situated between Sulawesi, Halmahera, and the Philippines. It lies in the northern sector of the biogeographic region of Wallacea, the transitional zone between Australopapuan and Asian biotas. Traditionally the archipelago was treated as a northern section of Sulawesi, with which it shares certain endemic taxa such as squirrels and cuscuses. However, more recent studies have highlighted the biogeographical differences between Sangihe and Talaud, with the former showing closer affinities to Sulawesi, and the latter having closer links with Halmahera (Riley, 2002; Koch et al., 2009a). Both also share some taxa in common with the Philippines, although connections between Sangihe and Mindanao seem stronger than between Mindanao and Talaud (Koch et al., 2009a; Louys et al., in press). Talaud currently hosts 27 species of amphibians and reptiles including an endemic species of monitor lizard (Koch et al., 2009a, b). The Talaud-Sangihe archipelago hosts 31 indigenous mammals, the majority of which are found only in Karakelong (21 species, of which 19 are bats and two are murids) and Sangihe (25 species, of which 12 are bats). Other than murids and bats, Salibabu in the Talaud Group also supports a cuscus, while Sangihe hosts three species of squirrel, one civet, one tarsier, and two cuscus species (Riley, 2002). At least 11 mammalian species have been introduced into the archipelago since historical times (Louys, pers. obs.).

\section{Alor and Pantar}

Alor and Pantar are situated on the eastern end of the Nusa Tenggara chain of islands. Alor and Pantar are currently separated by a narrow and shallow oceanic channel such that they were often connected together as a larger island during Pleistocene glacial conditions. They remained separate from the majority of the remaining Nusa Tenggara islands throughout the Quaternary though were intervisible (Kealy et al., 2017). The endemic terrestrial fauna of Alor and Pantar have never been systematically surveyed, and as such very limited information is available regarding its modern biodiversity. Previous studies have indicated the presence of the Sunda shrew on Alor (Kitchener et al., 1994), and our own surveys have revealed the presence of several species of Rattus, as well as Melomys, Mus, Crocidura, several species of small-bodied birds (quail, song birds, coucal), microbats, several species of small blossom fruit bats, amphibians, and reptiles (snakes and several species of small lizards) (Samper Carro et al., 2016; Hawkins et al., 2017). Archaeological excavations have revealed at least one giant rat and one large rat species, both now extinct (Hawkins et al., 2017). Several of the small mammals collected from owl roost deposits are currently undergoing genetic analysis to determine whether they might represent endemic variants. Nevertheless, these islands are significantly depauperate in endemic terrestrial vertebrates.

\section{Timor}

Timor is situated to the south of Alor and Pantar, and is located near the very eastern end of the Nusa Tenggara chain of islands. It represents the highest and largest of these. Prior to the 1990s, the only known endemic mammals of Timor were two species of shrew (Aplin \& Helgen, 2010). More extensive surveys of the island resulted in the discovery of several additional endemics including one native rodent (Kitchener et al., 1991). However, Timor held a higher level of endemism until relatively recently, with at least four now-extinct genera of large rodents and five native smaller murines present in archaeological deposits (Aplin \& Helgen, 2010). Older fossil remains indicate the presence of stegodons (dated to approximately $130 \mathrm{ka}$; Louys et al., 2016) in addition to a tortoise (Geochelone atlas, Hooijer 1971) and an undescribed species of very large varanid (Hocknull et al., 2009), all of which were likely coeval. Today, Timor supports a number of commensals and domestic species including monkeys, deer, pigs, cuscus, horses, and dogs.

\section{Sumatra}

Biogeographically, Sumatra belongs to the Sundaic subregion of the Oriental realm, however it was connected to the rest of Sundaland and Indochina during the majority of the Pleistocene, and its extant faunas are reflective of this fact (e.g., Leonard et al., 2015). It is currently home to 201 mammal species, of which nine are endemic to the island (Whitten, 2000). The fauna are largely Sundaic in character, but also includes more widespread species such as rhinos, elephants, tigers, tapirs, porcupines, as well as several species of deer and monkey, amongst others. Repeated and longstanding connections with the 
Southeast Asian mainland has resulted in very few recorded Pleistocene extinctions, with the only extinct species from the island deriving from the Dubois legacy collections restricted (to date) to the Sunda leopard and possibly a species of bovid (Louys et al., 2007). However, the endemic records of the Mentawai Islands off the west coast of Sumatra hint at more extensive local extinctions of Sumatran mammals during the Pleistocene, as several Mentawai species have closer genetic ties to Bornean conspecifics than Sumatran (Wilting et al., 2012). Detailed study of the demographic histories of select species indicates complex biogeographical legacies for mammals endemic to Sumatra. For example, the current range of the Sumatran orangutan Pongo albeii is a result of the interplay between sea-level changes, demography, anthropogenic factors, and volcanic eruptions over the scale of hundreds of thousands of years (Nater et al., 2015).

\section{Materials and methods \\ Survey methods}

Surveys were conducted largely on foot. For each village in an area of interest, we enquired of the local villagers if they knew of any caves or shelters in the area. When the villagers were happy to act as guides, we accompanied them to the caves. Land ownership and the nature of the dense vegetation in most survey areas meant we were restricted to caves and rockshelters known locally, as both visibility and movement through the vegetation was difficult and most caves were situated in gardens or on land owned by some member of the village. For each positively identified cave and rockshelter, we recorded geographical coordinates and photographed cave entrances (Table 1). On some occasions caves were observed by the roadside and investigated in a similar manner. Where possible, caves were penetrated, and each accessible chamber investigated for archaeology, modern surface deposits, and breccias. Where vertebrate faunal remains were identified, these were collected.

\section{U-Th dating}

Uranium-thorium (U-Th) dating targeted both speleothem associated with the breccias and fossil teeth directly. The U-Th dating approach is based on the premise that initial ${ }^{238} \mathrm{U}$ radioactively decays to stable ${ }^{206} \mathrm{~Pb}$ via a series of intermediate daughter isotopes, including ${ }^{234} \mathrm{U}$ (half-life: 245,250 \pm 490 years) and ${ }^{230}$ Th (half-life: 75,690 \pm 230 years) (Cheng et al., 2000). For speleothem, $\mathrm{U}$ is co-precipitated in the calcite (or aragonite) at the time of formation. Th is typically immobile in aquatic environments, thus little or no Th is incorporated into the speleothem crystal framework (Latham \& Schwarcz, 1992). The $\mathrm{U}$-Th age is then calculated by measuring the ratio of ${ }^{230} \mathrm{Th}$ (daughter product) relative to the parent U. U-Th dating of speleothems provides the time of their formation.

For speleothems, we dated flowstones both immediately underlying and overlying breccias, thus producing bracketing ages for the contained fossils.
For example, a basal flowstone will typically yield a 'maximum' age, while a capping flowstone will yield a 'minimum' age for the interbedded breccia. Where possible, we also targeted straw stalactites that had been incorporated into deposits. Due to their fragile nature, straw stalactites are easily dislodged from the cave ceiling and can be readily incorporated into underlying deposits during their accumulation. While direct U-Th dating of straw stalactites yields maximum ages for the associated deposits, they commonly approximate the true age of the deposit given their fast-forming nature (relative to other varieties of speleothem) and short 'life-histories' (St Pierre et al., 2012; Price et al., 2015).

Unlike speleothem, fresh bone and teeth contain little or no $U$. However, $U$ is generally taken up by such biological tissues following burial, with the radioactive decay chain to produce ${ }^{230} \mathrm{Th}$ beginning thereafter (Pike et al., 2002). Thus, in ideal situations, U-Th dating of bone and teeth generally provides minimum ages for the specimen under investigation (Sambridge et al., 2012). However, it is important to note that unlike speleothem, bone and teeth are open systems for $\mathrm{U}$, and $\mathrm{U}$ may subsequently become leached following uptake. Preferential loss of U over Th can lead to erroneously high ${ }^{230} \mathrm{Th} /{ }^{238} \mathrm{U}$ ratios, and therefore, age overestimation (Pike et al., 2002). The possibility for leaching can be recognised and tested by profiling for $\mathrm{U}$ concentration and ${ }^{230} \mathrm{Th}$ ages through a specimen (e.g., Price et al., 2013).

In total, we produced 20 new ${ }^{230} \mathrm{Th}$ ages for speleothems and teeth (including $U$ concentration and age profiling of three fossil teeth) for suitable cave deposits. Detailed sample selection and physical pretreatment protocols for such samples are described in Zhao et al. (2009), St Pierre et al. (2012) and Price et al. (2013), for flowstones, straw stalactites, and teeth, respectively. Sample measurement was conducted on a Nu Plasma multi-collector inductively coupled plasma mass spectrometer (MC-ICP-MS) at the Radiogenic Isotope Facility, The University of Queensland, following procedures described in Zhou et al. (2011) and Clark et al. (2014). Ages are reported as years BP for comparison with radiocarbon ages.

\section{Radiocarbon}

Radiocarbon dating primarily targeted fossils found in breccia and unconsolidated deposits, aiming to establish when the organism died through the radioactive decay of ${ }^{14} \mathrm{C}$ to ${ }^{14} \mathrm{~N}$. In tropical environments bone collagen, the fraction of bone isolated for dating, degrades rapidly and it is often impossible to directly radiocarbon date all but the youngest bones. Charcoal is affected in a similar manner, and so shell may be the only material available to radiocarbon date. Unfortunately calibration of radiocarbon dates on shell is complicated. Radiocarbon dates need to be calibrated to account for the variation in the ${ }^{14} \mathrm{C} /{ }^{12} \mathrm{C}$ ratio in the atmosphere or marine system over time. Whilst alterations in the atmosphere are relatively well understood, particularly in the Holocene (Reimer et al., 2013), those in the marine system are more complicated. Local offsets from the marine calibration 


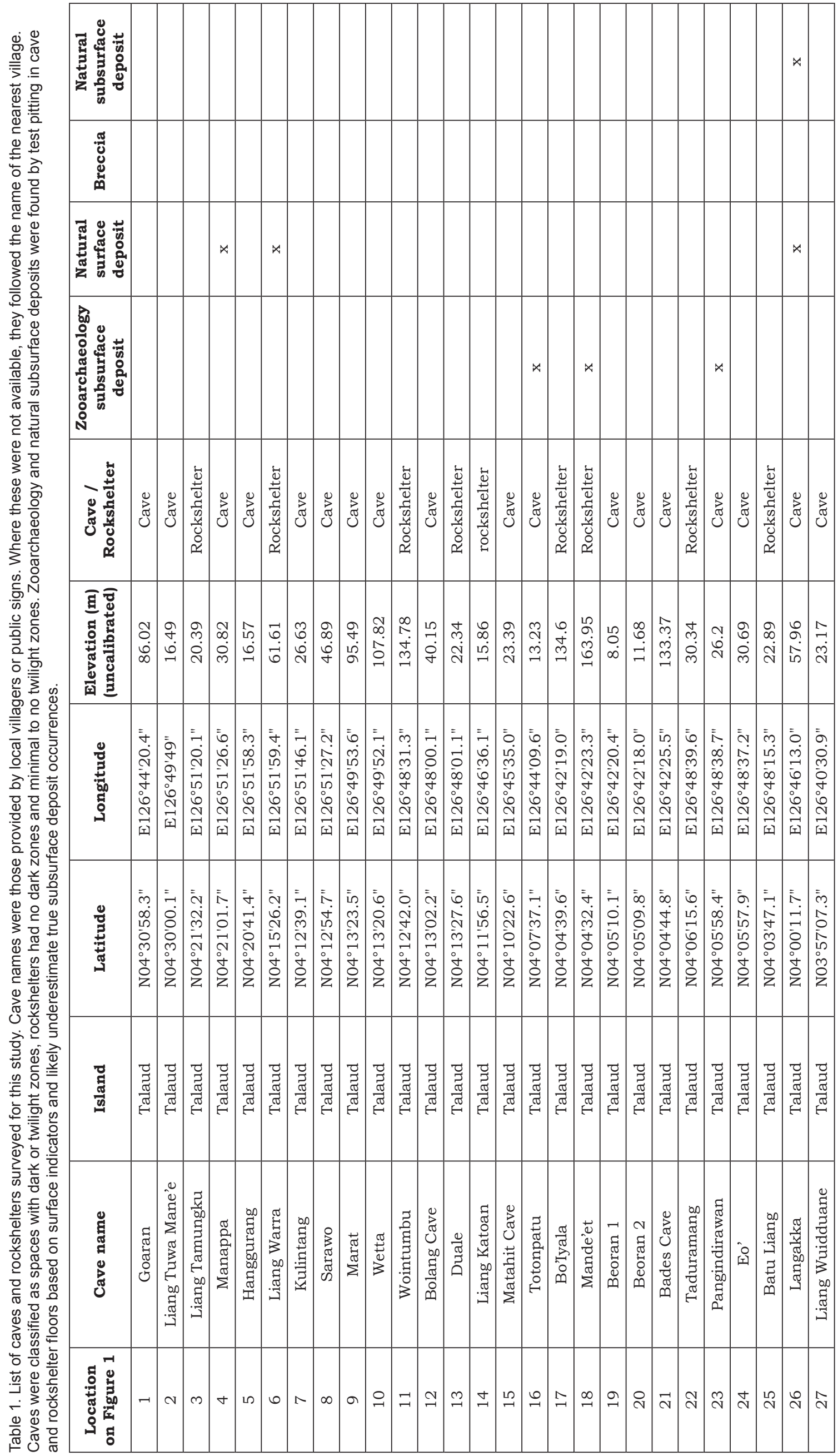




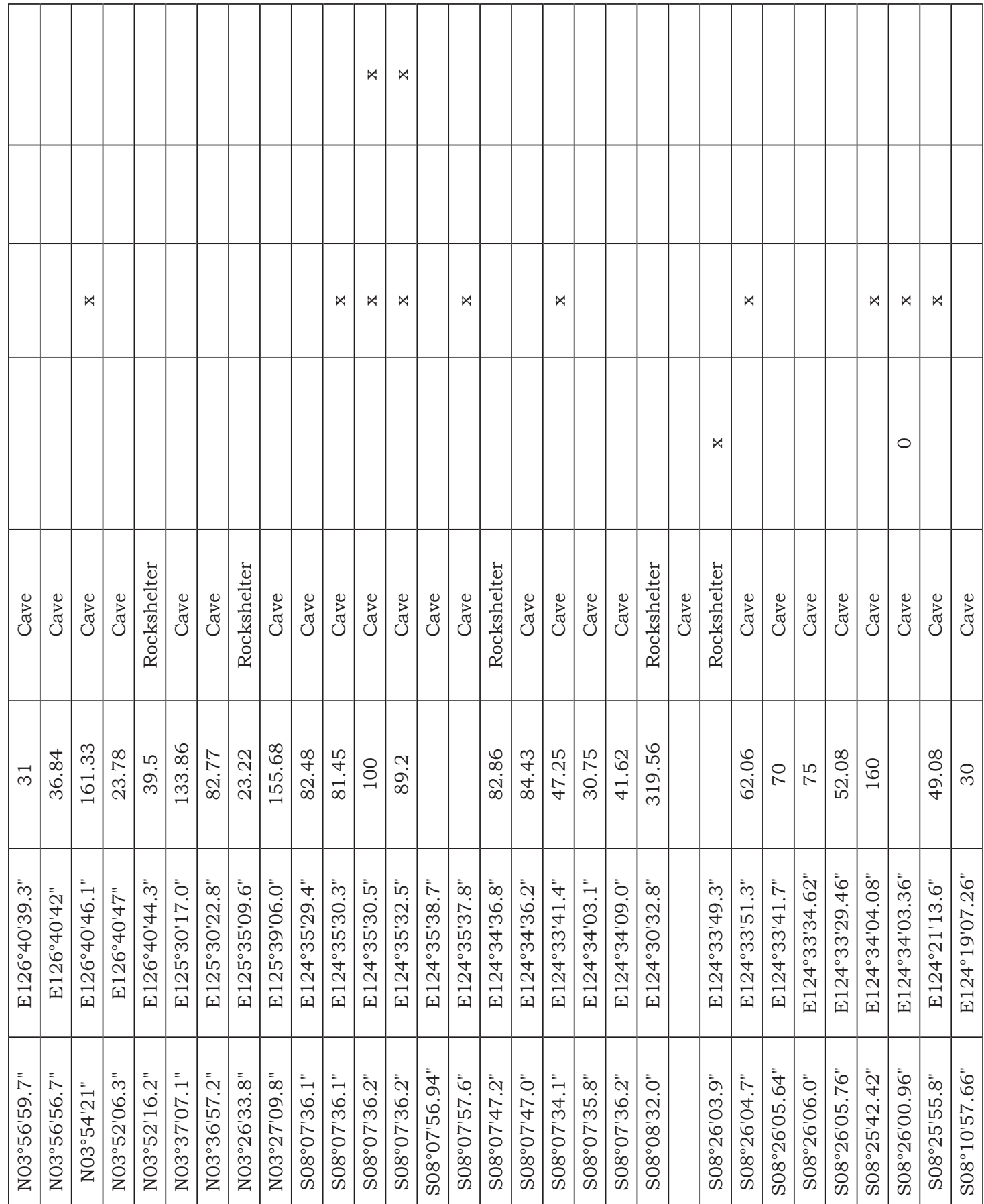

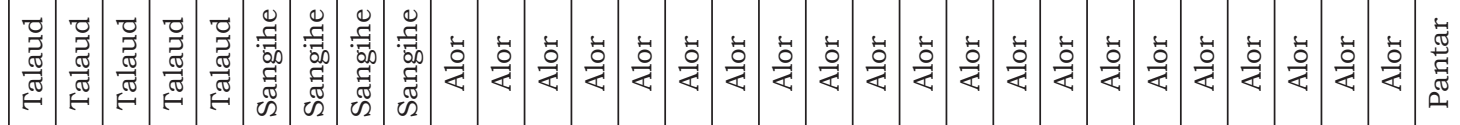

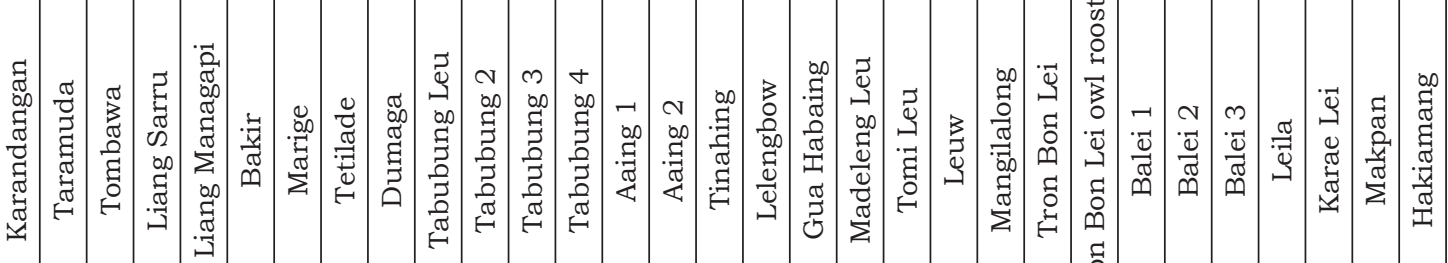
옵

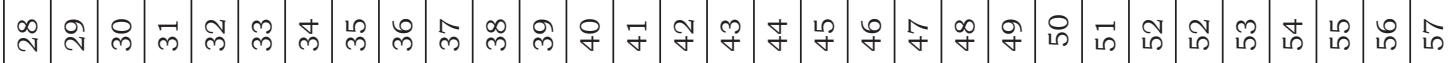




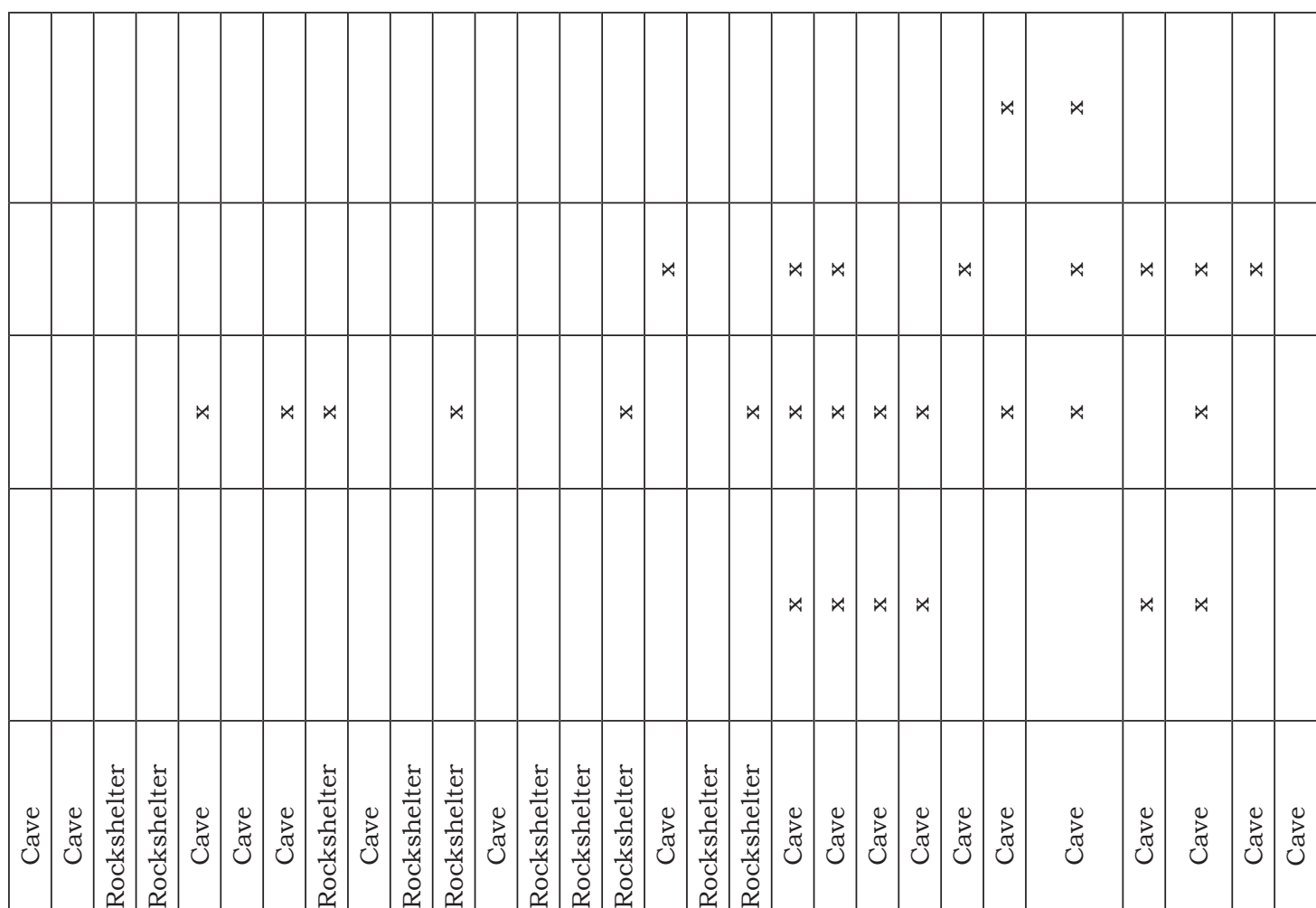

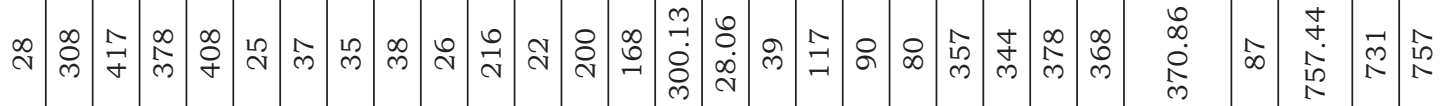

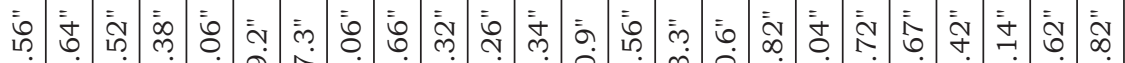

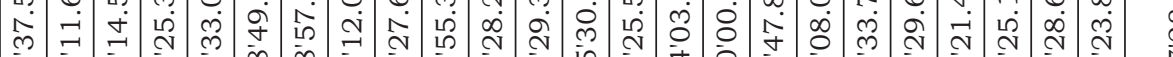

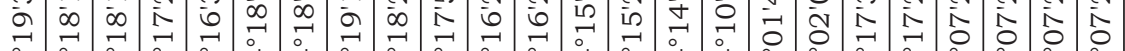

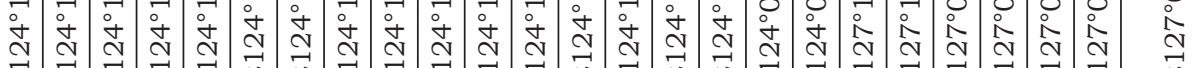

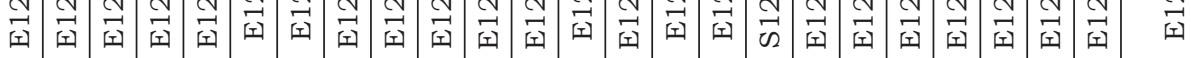

$=\infty \bar{\infty} \equiv$

กิ

वे :

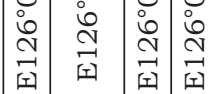

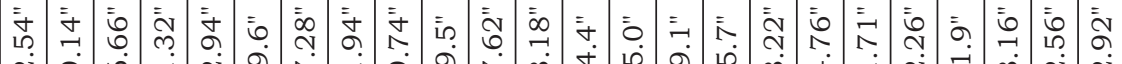

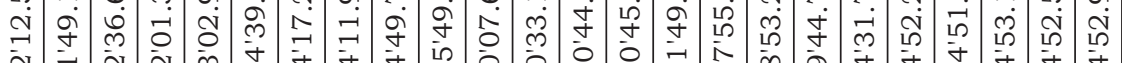

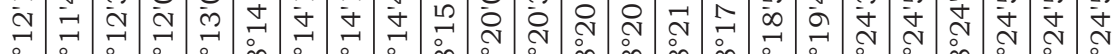

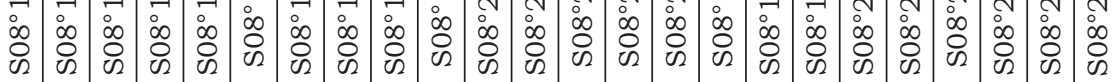

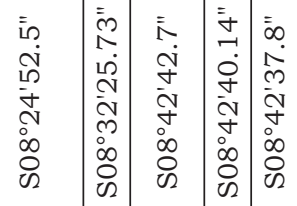

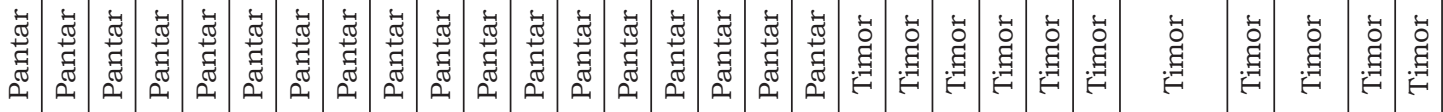

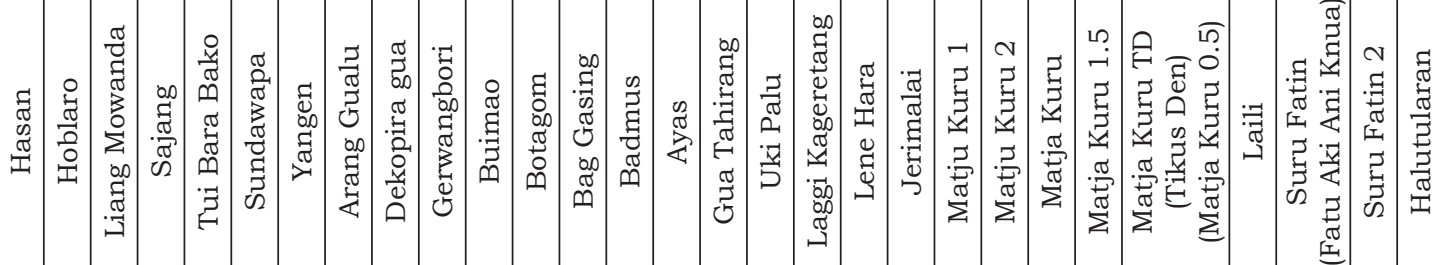

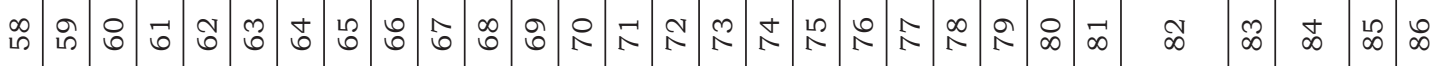




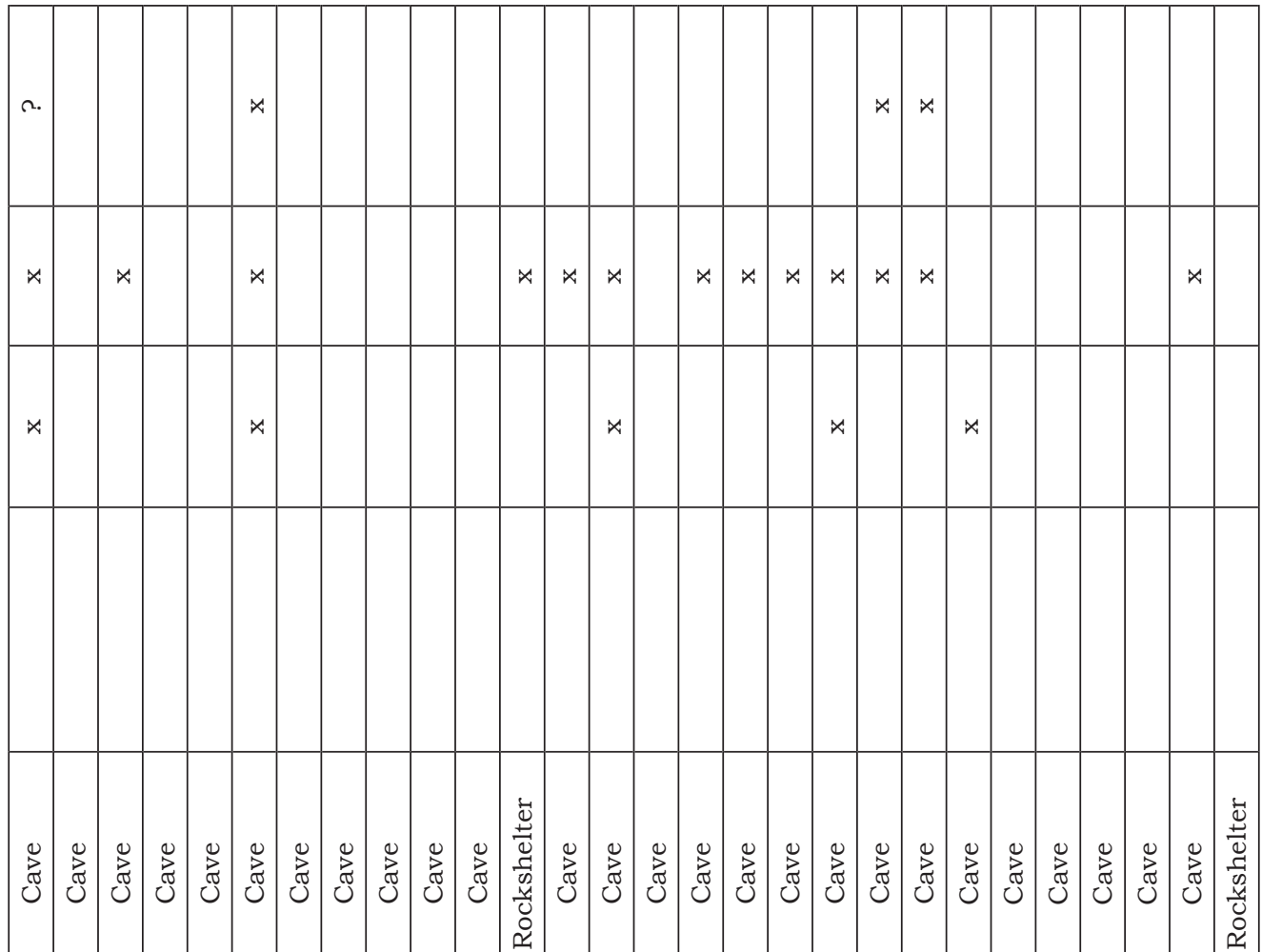

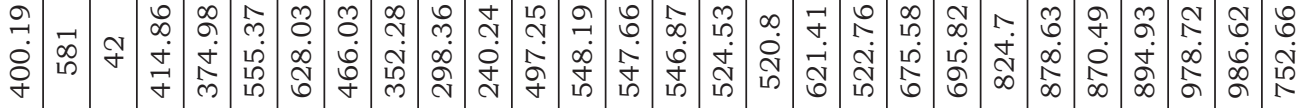

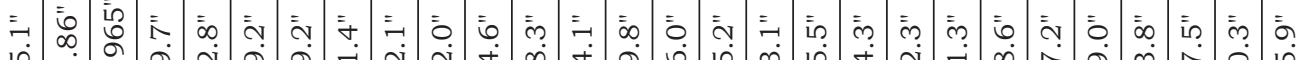

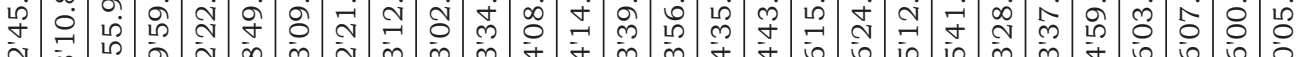

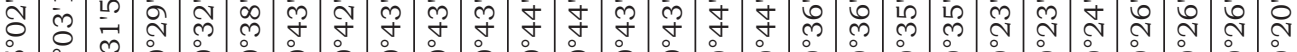

in

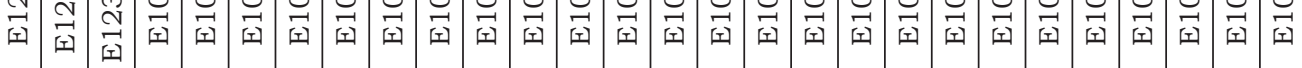

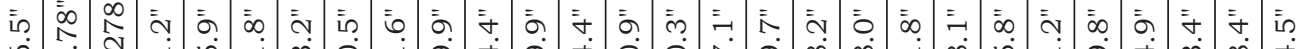

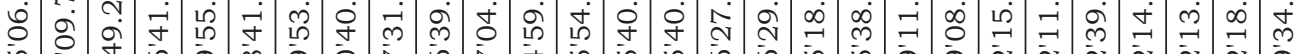

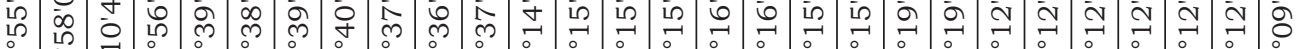

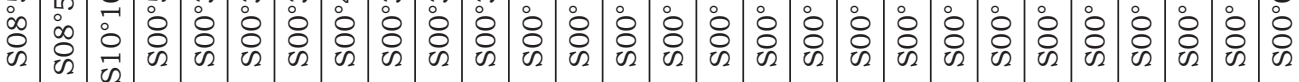

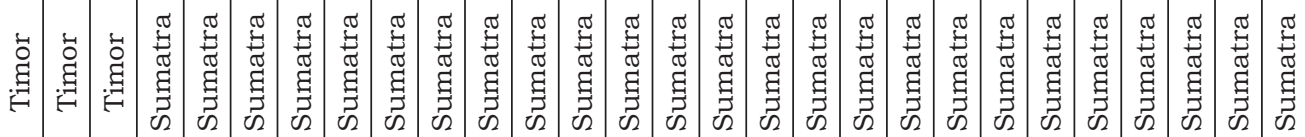

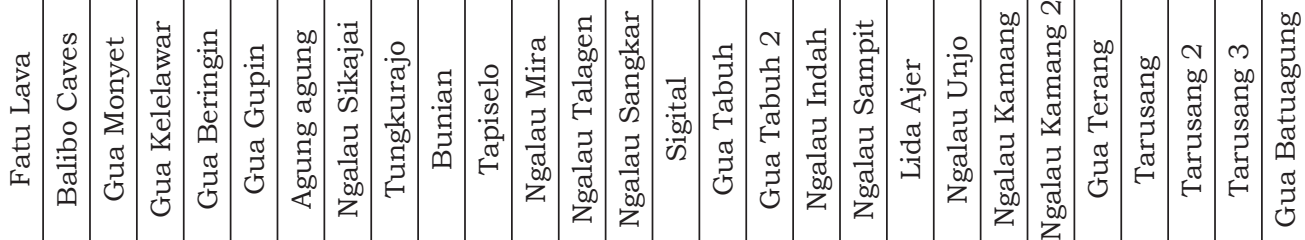

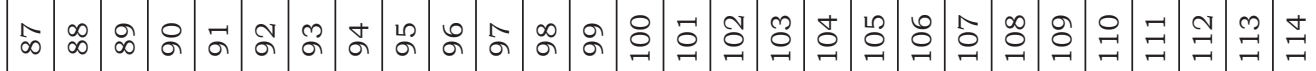


curve, or $\Delta \mathrm{R}$ values (Stuiver \& Braziunas, 1993), are poorly known around Indonesia and may have varied by several hundred years during the past (McGregor et al., 2008). Freshwater reservoir effects have the potential to be much larger than marine reservoirs where a portion of the dissolved inorganic carbon in river, lake and estuarine environments may be derived from limestone in the water catchment (Lanting $\&$ van der Plicht, 1998). This type of reservoir is difficult to quantify without paired organic and freshwater samples from closed contexts, and dates on shell from fresh- or brackish- water environments or on human bone must be regarded as potentially overestimating the true age of the sample.

This study aimed to radiocarbon date human bones, shells, large murid bones, and charcoal fragments lithified in breccia. The latter two samples (large murid bones and charcoal from Matja Kuru TD) did not survive pre-treatment. Three radiocarbon dates were obtained, two on shell and one on human bone. All were late Holocene in age. Dates on shell were processed at the Waikato radiocarbon facility, New Zealand (lab code Wk-), with samples cleaned in ultrasonic baths, acid washed using $0.1 \mathrm{~N} \mathrm{HCl}$, rinsed and dried. The date on human bone was obtained from the Australian National University (lab code S-ANU-) using an ultrafiltration protocol as described in Wood et al. (2014) and Fallon et al. (2010). Ages are reported as calibrated years before present (cal BP), where BP is 1950 AD.

\section{Imaging}

This study utilised the DINGO radiography/ tomography/imaging station, located on the thermal HB 2 beam, tangentially facing the $20 \mathrm{MW}$ OpenPool Australian Lightwater (OPAL) reactor housed at the Australian Nuclear Science and Technology Organisation (ANSTO), Lucas Heights, New South Wales, Australia to non-invasively image breccia prior to acid dissolution. The DINGO facility utilises a quasi-parallel collimated beam of thermal neutrons from OPAL with a maximum spectrum intensity at $1.08 \AA(70 \mathrm{meV})$ and full-width-at-half-maximum (FWHM) of $0.9 \AA$ (100 meV), and two collimation (L/D) ratios of 500 or 1000 (Garbe et al., 2011), where L is the neutron aperture-to-sample length and D is the neutron aperture diameter. For all measurements described here, an L/D ratio of 1000 was used to ensure highest available spatial resolution.

Equally-spaced angle shadow-radiograph projections, and both dark (closed shutter) and beam profile (open shutter) images were obtained for calibration before initiating shadow-radiograph capture. A cosmic ray filter was applied to all images to reduce data noise associated with non-neutron background radiation detection events. Neutrons were converted to photons using a $100 \times 100 \times 0.05 \mathrm{~mm}{ }^{6} \mathrm{LiF} / \mathrm{ZnS}(\mathrm{Ag})$ scintillator; photons were then detected by an Andor IKON-L CCD camera (liquid cooled, 16-bit, $2048 \times 2048$ pixels) coupled with a Makro Planar $100 \mathrm{~mm}$ Carl Zeiss lens to obtain a pixel size of $20 \mathrm{~mm}$. A total of 1441 projections with an exposure length of $10 \mathrm{~s}$ were obtained every $0.25^{\circ}$ as the sample was rotated over $360^{\circ}$ about its vertical axis. Tomographic reconstruction of the raw data was performed using Octopus Reconstruction v.8.8 (Inside Matters NV), yielding a voxel resolution of $29 \times 29 \times 29 \mathrm{~mm}^{3}$, and virtual slices perpendicular to the rotation axis. When these slices are stacked in a sequence, they form a three-dimensional volume image of the sample. The reconstructed volume data were rendered and visualised using VGStudio Max 2.2 (Volume Graphics GmbH).

\section{Results \\ Talaud}

Thirty-two caves and rockshelters were surveyed on Talaud over approximately three weeks. A strict distinction between rockshelter and cave was mostly impossible with the majority of the caves little more than very shallow, single chambered cavities with wide entrances (Fig. 2a). One vadose spring was documented (Fig. 2b) and partly surveyed, which produced one of the few instances of active stalactite formation observed on the island (Fig. 2c). Most caves were spongework and ramiform and formed from highly porous, reefal limestone (Fig. 2d, e). Two caves had entrance passages of vadose origin; however these were not explored substantially due to access difficulties. Two archaeological excavations were conducted (Mande'et and Pangindirawan). Mande'et is described in detail in Louys et al. (in press), and produced the largest faunal assemblage from the island: a total of 615 faunal fragments, the majority of which were raptor-deposited rodents. The latter site produced only ten faunal fragments: five vertebrate fragments, one rat tibia and four fish fragments from the top $10 \mathrm{~cm}$ of the deposit. One cave (Totonpatu) had ceremonially placed human skeletal remains on the surface.

Only four caves had surface fauna present $(12.5 \%$ of caves), being mostly bats and rodents. Of these, only one, Langakka, had subsurface deposits. Langakka (Fig. 2f) is dual-chambered with a north-eastern entrance that opens into a medium-sized chamber approximately $4 \mathrm{~m}$ deep, which in turn opens into a larger chamber measuring approximately 15 x $12 \mathrm{~m}$. The cave floor consists of well consolidated red clay in parts eroded through bioturbation and water flow. Although surveyed, no fauna was observed in any of the exposed sections. A very small test pit was dug at the northern end of the larger chamber in a small limestone cavity (Fig. 2g). This produced one vertebra of Varanus sp. cf. Varanus lirungensis as well as several vertebrae and a cranial fragment of a small Serpentes gen. et sp. indet. To date, these bones constitute Talaud's entire naturally deposited vertebrate fossil record.

\section{Sangihe}

Four caves/rockshelters were examined over the course of a week on Sangihe. These were formed from volcanic breccias and boulders and were of limited spatial extent (Fig. 3a-d). While some provided either natural or anthropogenic sediment traps (Fig. 3b), they were also often conduits for periodic fast water flow (Fig. 3c). Despite evidence of use by swallows 

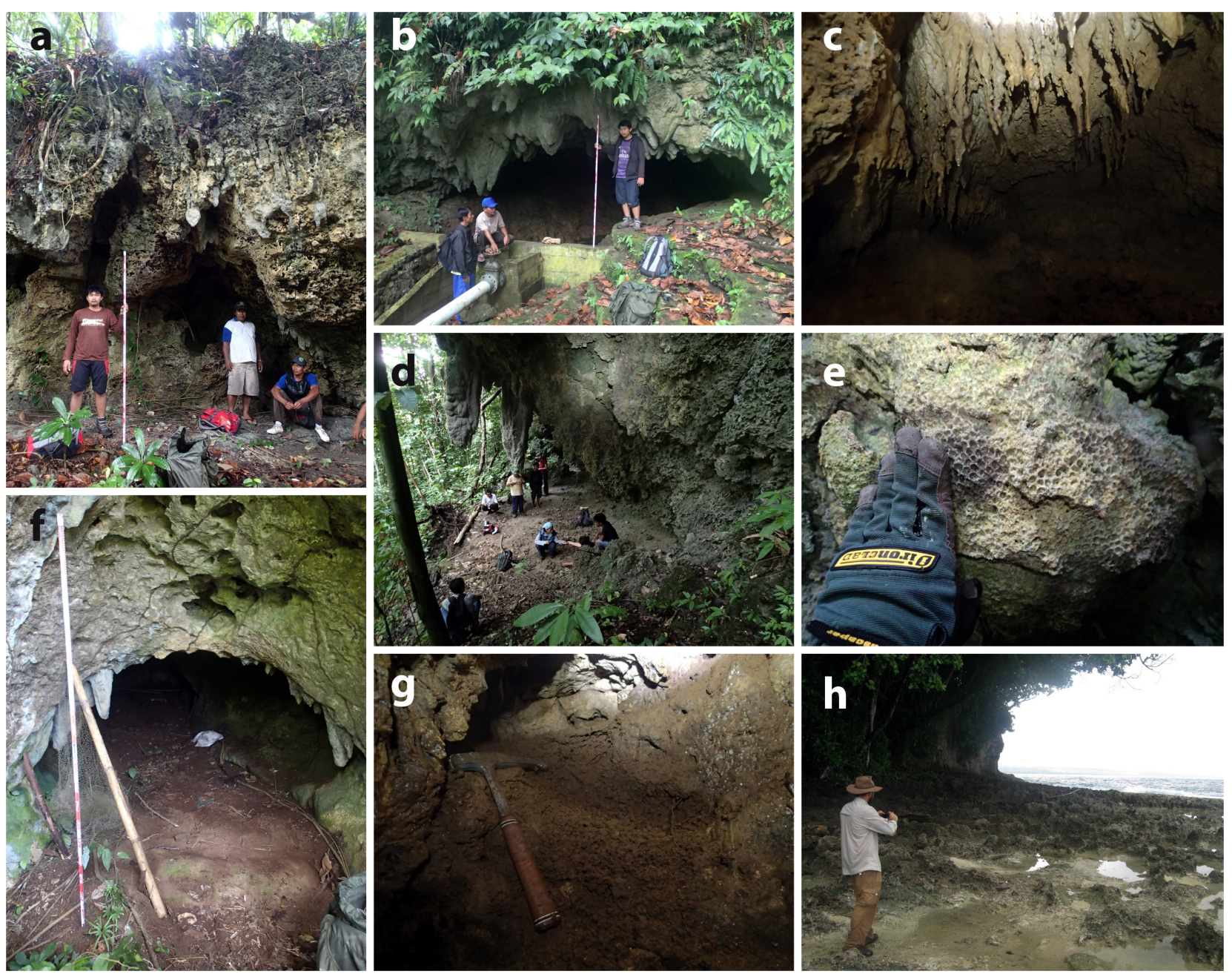

Fig. 2. Talaud Islands. a) Taduramang Cave, showing vertical dissolution forming entrances; b) Wetta Cave, horizontal entrance and spring; c) active stalagmite formation inside Wetta Cave; d) Wointumbu rockshelter; e) coral structure on the walls of Wointumbu; f) Langakka Cave entrance; g) sediment deposit in Langakka Cave producing recent faunal remains; h) east coast of Alor, showing recent uplift of limestone.
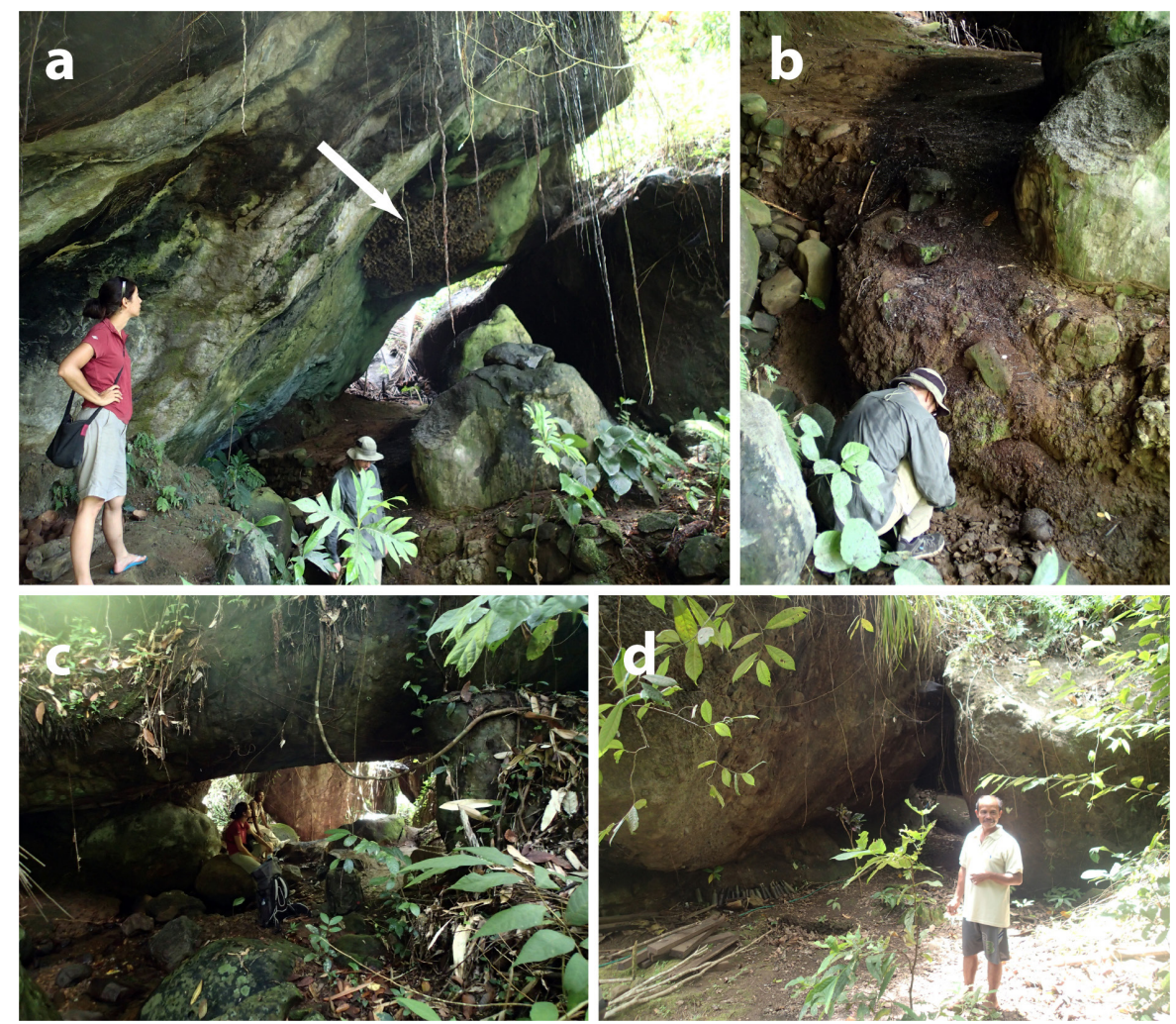

Fig. 3. Sangihe Island. a) Bakir Cave, arrow indicates active swallow's nest; b) sediment trap formed in Bakir Cave created by artificial rock wall; c) Marige Cave, showing water channel active during rains; d) Tetilade rockshelter. 
(Fig. 3a), no surface or subsurface faunal remains were observed.

\section{Alor}

Nineteen caves and rockshelters were explored on Alor over a period of approximately two weeks. Survey efforts focused predominately on the Kabola Peninsula. Like Talaud, the majority of the caves in this peninsula were shallow, single-chambered, spongework to ramiform and formed from highly porous, reefal limestone (Fig. 4a). Cave entrances ranged from very small, horizontal, and narrow to very wide, open and facing the ocean (Fig. $4 \mathrm{a}$, b). The latter may represent the early stages of flank margin speleogenesis (Mylroie and Carew, 1990) or wave-cut platforms. They were unevenly distributed across the five limestone terraces documented for the peninsula (Hantaro et al., 1994) with the highest cave explored at an elevation of $320 \mathrm{~m}$. In the southwestern sector of the Kabola peninsula, as well as the southern coastline of Alor Island itself which was surveyed, the caves are formed in the volcanic Alor Formation. Such caves were found either directly on the coast and formed from erosion due to wave action (Fig. 4c), or were slightly more inland and at higher elevations and formed from fluvial erosion (Fig. 4d).

Five caves in the Kabola Peninsula yielded surface faunal remains: Gua Habaing, a young limestone cave with a relatively large main chamber with significant sedimentary accumulation on the cave floor; Aaing 2, a large rockshelter and cave formed from collapse along a joint or fault in the overhanging limestone; and Tabubung 2, 3, and 4 (Fig. 4e-g). Tabubung 2 and 3 were small and shallow niches within a coraline limestone in the terrace situated at $80 \mathrm{~m}$ elevation. Both had relatively wide (compared to their depth) entrances above ground level, and exhibited minimal sedimentation. Tabubung 4's entrance sloped upwards (Fig. 4e). This cave exhibited more speleothem formations than Tabubung 2 or 3, with significant flowstone observed starting approximately $5 \mathrm{~m}$ into the cave. The cave itself is a narrowing main chamber, with some very small side chambers mostly filled with limestone collapse. The cave narrows from 3 $\mathrm{m}$ high and $6 \mathrm{~m}$ wide at the entrance to approximately $2 \mathrm{~m}$ wide and $0.5 \mathrm{~m}$ high (Fig. $4 \mathrm{~g}$ ), at which point it becomes inaccessible. At the rear of the explored section of the cave a flowstone pool measuring $120 \mathrm{~cm}$ long and $58 \mathrm{~cm}$ wide in a roughly triangular shape was observed. This pool was dry and created a sediment trap approximately $13 \mathrm{~cm}$ deep, which was excavated. The top layer of sediment was loose and could be easily swept and collected. Below this, at approximately 5-10 $\mathrm{cm}$ depth depending on the location within the pool, more compacted sediment was observed. The more consolidated sediment exhibited several conical depressions most likely caused by wasps (Fig. 4f), and was excavated separately with trowels and chisels. At the far end of the pool a limestone boulder had fallen into the pool at a late stage, and exhibited some subsequent flowstone formation, cementing some of the sediment including at least one murid longbone (Fig. 4h). Two ages were produced for this deposit on the basis of Terebralia palustris shells recovered from the excavation. It was not possible to establish a robust $\Delta \mathrm{R}$ value as this mollusc lives in brackish water. Nevertheless the dates were calibrated against the Marine13 calibration curve (Reimer et al., 2013) in OxCal 4.2 (Ramsey, 2009), and should be viewed tentatively. The shell from the upper, unconsolidated sediment was dated to 2012 - 1863 cal BP (Wk41372, $2324 \pm 20 \mathrm{BP})$, while the shell from the lower, more consolidated sediment was dated to 1520 - 1376 cal $\mathrm{BP}$ (Wk41123, $1902 \pm 20 \mathrm{BP})$, indicating disturbance and mixing of consolidated and unconsolidated layers, with the higher shell likely to have moved upwards through the actions of invertebrates. The species recovered from this deposit include species of Rattus (currently undergoing genetic sequencing), a pteropodid, Crocidura sp., and Gekko sp.

Surface vertebrate accumulations in volcanic caves were a result of the actions of owls, and three active owl roosts were observed during surveys of the southern coast of Alor, including one in the rockshelter complex of Tron Bon Lei (Fig. 4k), in a cave adjacent to the archaeological excavation described in detail in Samper Carro et al. (2016). The Tron Bon Lei owl roost deposit was collected and taphonomic analysis and description of these remains is presented elsewhere (Hawkins et al., 2017). The archaeological excavations at the Tron Bon Lei rockskelter produced thousands of fish and marine shellfish remains of anthropogenic origins from three test pits (Samper Carro et al., 2016), human remains in a burial context (O'Connor et al., in press), very small numbers of terrestrial microvertebrates including rodents, blossom fruit bats, microbats, frog/toads, lizards, snakes and birds, all of which were deposited by raptors, and finally small numbers of macrovertebrates such as fruit bats, marine turtles, and giant rats that appear to have been anthropogenic deposits (Hawkins et al., 2017). Of particular note was the presence of long lava tube caves (Fig. 41) on the southern coast of Alor, in which active owl roosts were observed and excavated.

\section{Pantar}

Nineteen caves and rockshelters were examined on Pantar over two weeks. Surveys focused on the coastal areas, and encompassed both volcanic and limestone outcrops. Limestone caves were formed from horizontally bedded strata, and largely either took the form of low-ceilinged elliptical phreatic entrances and chambers (Fig. 5a), or joint-controlled dissolutionbrecciation caves (Fig. 5b). The limestone ranged from massive to highly fossiliferous, coral-dominated blocks (Fig. 5c). One extensive sinkhole, named Tui Bara Bako, was recorded (Fig. 5d), measuring approximately 30 × $30 \mathrm{~m}$. Rockshelters and caves in volcanic host rocks were formed as a result of tectonic uplift and local collapse (Fig. 5e, f), and were mostly vertically extensive, large, and single-chambered in the case of the caves. Some smaller, burrow-like tunnels were also recorded in volcanic conglomerates (Fig. 5g). These were invariably shallow, single-chambered tubes. Undercutting of volcanic conglomerates and breccias was commonly encountered near the shore and rivers. 


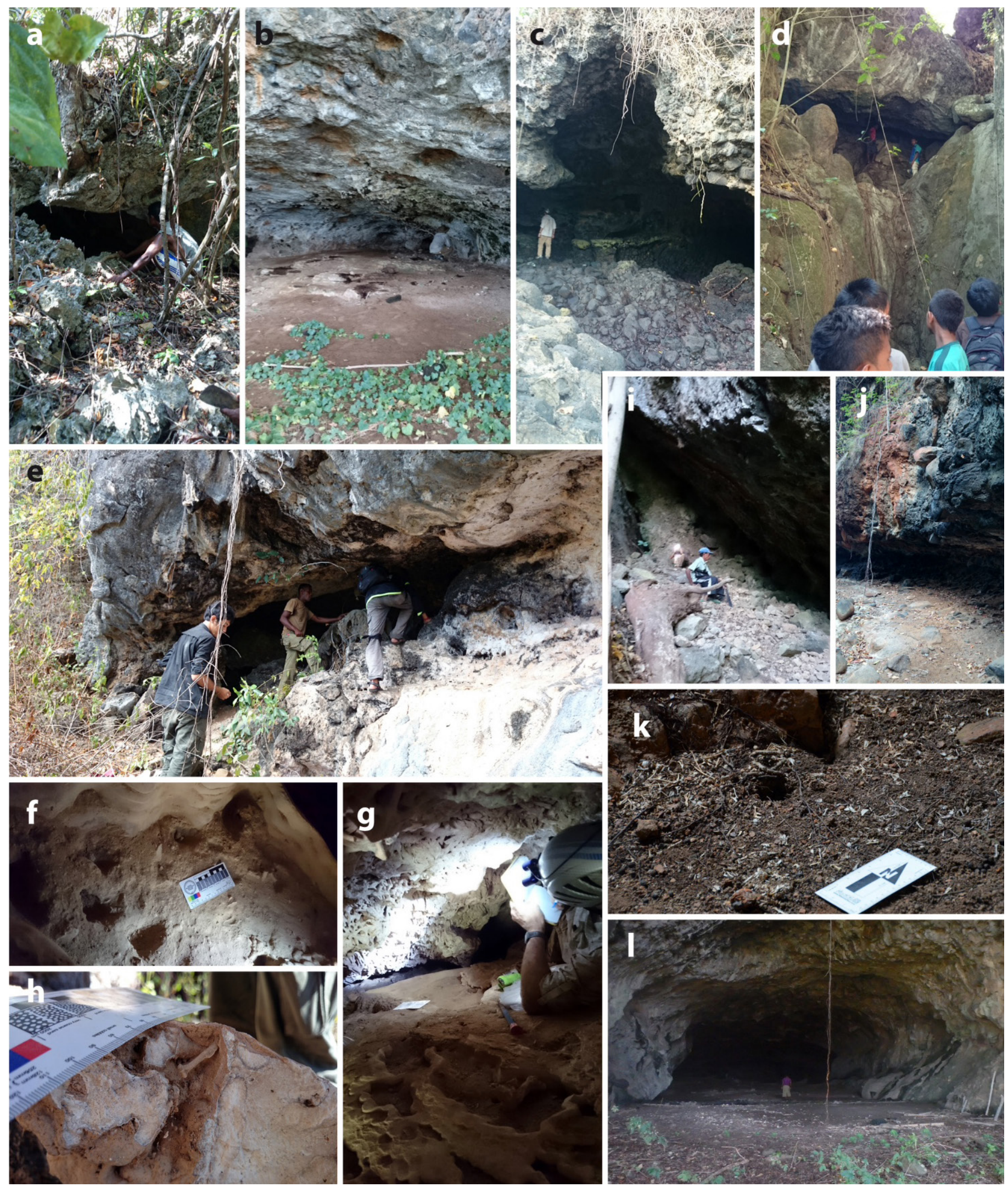

Fig. 4. Alor Island. a) Aaing 1, showing a small, horizontal entrance; b) Lelafutung Cave entrance; c) volcanic agglomerate cave near the village of Mangilalong; d) Tomi Leu, a volcanic cave with active water channel; e) entrance to Tabubang 4; f) flowstone pool showing unconsolidated sediment prior to excavation in Tabubang 4 , depressions likely caused by wasp burrowing are clearly visible; g) Tabubang 4 during excavation;

h) Tabubang 4 capping flowstone showing captured murid humerus; i) Leila Cave, volcanic vertical fissure with active owl roost observed at the top; j) Balei Cave 2, a shallow volcanic cave formed from undercutting by river; k) Tron Bon Lei owl roost deposit; I) Makpan Cave, volcanic tube cave. 
Six of the rockshelters and caves produced surface deposits. Most of these were scarce, lightly scattered microfaunal remains (rodents and reptiles) representing at most a few individuals. One active owl roost was recorded, and abundant microfaunal remains collected. Of particular and unusual interest on Pantar was the discovery of a Homo sapiens-breccia deposit in a limestone niche near the shore (Fig. 5h, i). The niche has a diameter of $3 \mathrm{~m}$, and is conical in shape, tapering into the wall for a distance of $4 \mathrm{~m}$. The breccia in this deposit consists of thin smears of cemented bone and lithics on both walls of the niche, with unconsolidated and unlithified skeletal material on the niche floor (Fig. 5h). This is likely a result of active dissolution of the breccia. The alternative scenario, that the loose skeletal material may be in the process of active cementation, is highly unlikely due to the limited extent and location of the breccia above the floor deposits, no observed water flow, and the lack of carbonate precipitation triggers. Local villagers suggested that these remains were from pirates who had been killed by their ancestors, and their bones deposited in the niche. However, high quality collagen $(2.7 \%$ collagen yield, C:N 3.2, 43.8\%C) was recovered from one of the mandibles providing an age of 2,315 - 2,141 cal BP (against IntCal13 (Reimer et al., 2013), S-ANU 51939, $2200 \pm 30 \mathrm{BP})$. Without a large scale faunal database for comparison it is difficult to assess whether the date may be affected by a radiocarbon reservoir effect, but a slightly elevated $\delta^{13} \mathrm{C}$ would allow for some consumption of marine or freshwater resources $\left(\delta^{13} \mathrm{C}:-16.7 \%\right.$ o, $\delta^{15} \mathrm{~N}$ : $8.5 \%$ o), suggesting the date may overestimate the age of the individual by up to a few hundred years. However, the date still suggests that these remains represent a much older burial.
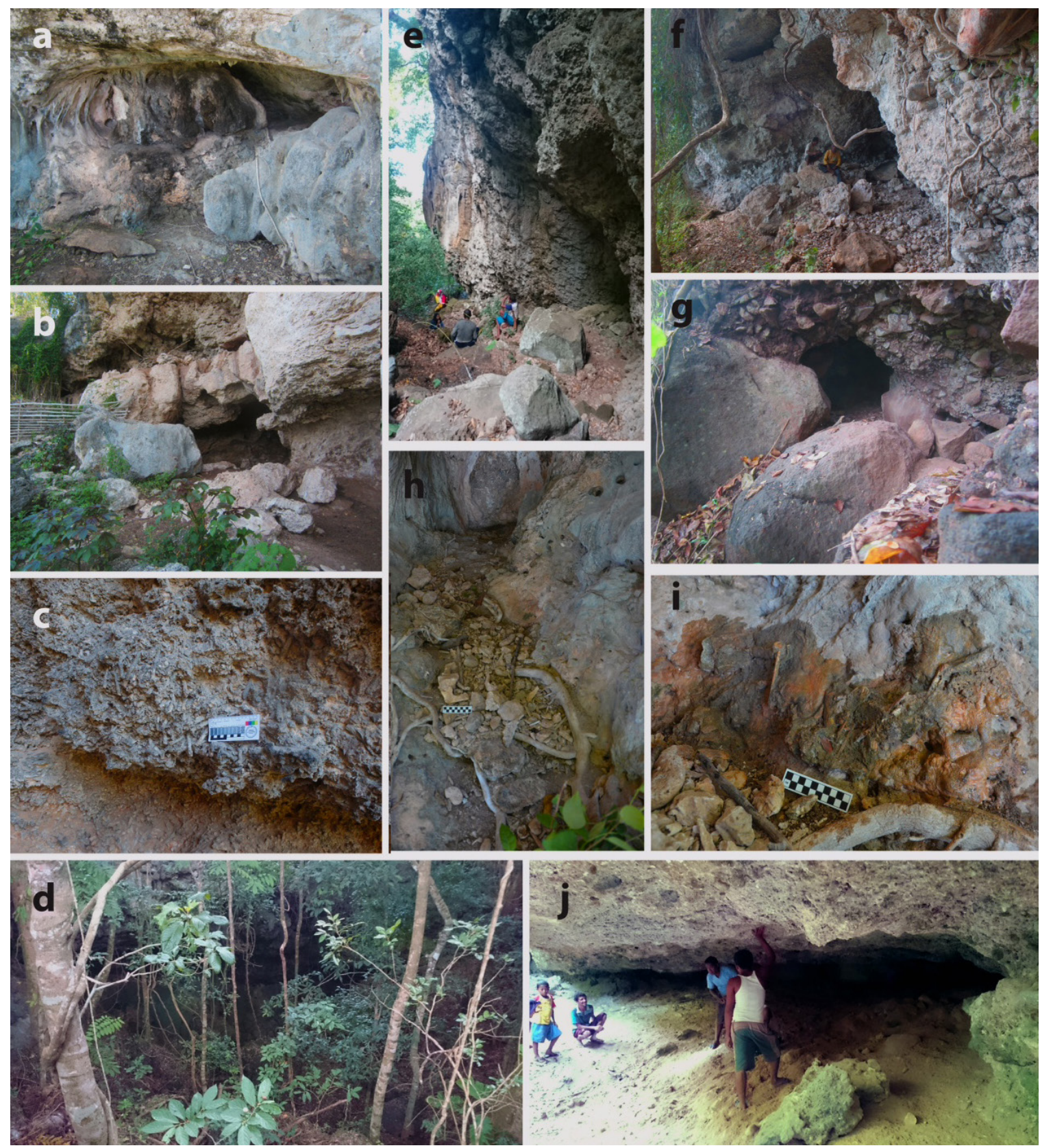

Fig. 5. Pantar Island. a) Gua Tahirang 2, showing horizontal, phreatic entrance; b) Sindawapa, a joint controlled cave; c) coral dominated limestone outcrop; d) Tui Bara Bako, large sinkhole; e) Buimao, a rockshelter formed from recent uplift and collapse; f) Ayas Cave, in conglomerate host rock; g) Belldaing Cave, a small volcanic niche; h) Gua Tahirang showing loose human remains on the floor of the niche; i) human-bearing breccia of Gua Tahirang, this has been wet with water to enhance contrast; j) Dekopira Gua, a volcanic cave formed from undercutting of underlying sediment. 


\section{Timor}

The scientific investigation of caves in Timor has been carried out by a number of researchers from the 1960s, and in Timor-Leste hundreds of caves have been recorded, including by several authors of this paper and over the course of more than a decade of research. Here we focus primarily on areas specifically surveyed for vertebrate accumulation mechanisms during fieldwork in Timor-Leste and Indonesia in 2014. Arguably the most well-known of these caves are the archaeologically important Lene Hara (Fig. 6a) and Jerimalai caves (Fig. 6b) of Lautém District in eastern Timor-Leste (Fig. 1). These have produced some of the earliest records of modern humans in Island Southeast Asia (O'Connor et al., 2002, 2011). In addition to abundant artefacts, these assemblages preserve detailed records of fauna ascribed largely to human subsistence activities. Jerimalai, for example, hosts the oldest record of pelagic fishing in the world (O'Connor et al., 2011). As well as evidence of extensive marine resource utilisation, these coastal sites preserve more limited numbers of terrestrial vertebrates, namely giant and modern rats, bats, lizards, snakes, anurans, and birds. Preliminary examination of these indicates they represent a palimpsest, combining both human refuse and regurgitation by owls and other raptors.

Lene Hara and another cave from Timor-Leste, Laili, have been subjected to detailed geomorphological analysis in an effort to elucidate depositional processes (O'Connor et al., 2010, 2016). Laili is a relatively large, single-chambered cave situated in a karstic limestone ridgeline $\sim 86 \mathrm{~m}$ elevation, while Lene Hara is a large solution cave formed in wellbedded folded limestone in an uplifted coral terrace at $\sim 100 \mathrm{~m}$ elevation. In addition to unconsolidated archaeological deposits, both sites are notable for preserving breccia containing archaeological material. Lene Hara preserved a significant breccia adhering to the base of a large speleothem column (Fig. 5 in O'Connor et al., 2016), containing shells, bones, and lithic artefacts (Fig. 6a). Dating of two Tectus sp. shells produced ages between $\sim 43-41$ ka (O'Connor et al., 2010). Significantly, marine gastropods with carbonate encrustation were also recovered from the surface and near-surface, the latter providing a date of $\sim 43 \mathrm{ka}$ (O'Connor et al., 2016). This was interpreted by the authors as late Pleistocene breccia eroding and being incorporated into younger deposits. The Laili breccias, meanwhile, preserve Holocene deposits otherwise missing from the archaeological excavation (O'Connor et al., 2016).

Other caves in Timor-Leste have produced breccias (Table 1); however, these all represent collapsed breccias and none contain any evidence of vertebrate fossils (Fig. 6c). In west Timor, in a cave system near Kupang, a horizontally extensive, approximately $1 \mathrm{~m}$ thick breccia was recorded hosting giant rat remains, turtle, and other vertebrate fragments. This breccia has yet to be acid-processed or dated. On the basis of field observations, it appears likely that at least two fossil depositional events are recorded in this cave, as breccia on either side of the end chamber are found at different levels with obviously different clast to matrix ratios. Both are clay-rich, lack any obvious pisoids, and have large limestone clasts predominately rounded to sub-rounded (Fig. 6d). This suggests initial limestone clast formation in a high energy environment, possibly near-shore. However, the presence of near complete skeletal elements such as giant rat long bones and mandibles, the presence of many fragile terrestrial molluscs, high clay content, and the lack of any bedding or sedimentary structures suggests that each breccia represents a discrete mass movement event incorporating previously rolled limestone clasts. Several niches and wave-cut platforms facing the ocean, similar to that described from Pantar, were observed on cliff walls near this cave (see O'Connor et al., 2015).

The Matja Kuru ridge is an uplifted limestone terrace situated near Lake Ira Laloro. Two archaeological sites in two caves along the ridge, Matja Kuru (MK) 1 and 2, have been described, the latter of which preserves evidence of human use from $\sim 36 \mathrm{ka}$ onwards (Veth et al., 2005; Langley \& O'Connor, 2016). In fact, the entire ridge is composed of ramiform grading to spongeform caves, the majority of which have not been surveyed and most of which are interconnected through dissolution passages and intersecting fissures. The largest cave explored to date is the eponymous Matja Kuru Cave, located east of MK2. It has not been mapped, but consists of large, interconnected chambers, with abundant stalagmites, stalactites, and tabular flowstones. Breccia was recorded in this cave, but these were not fossiliferous. Between MK1 and MK2, several dissolution chambers with relatively narrow openings to the photic zone and connected to open chambers verging on rockshelters are present. These were not targeted for archaeological excavation as they provide no evidence of living floors or favourable conditions for use. Nevertheless the depocenters in this area are represented by a series of inter-boulder spaces and solution flutes, which have accumulated sediment and fauna. Excavation and sieving of these deposits has produced predominately microfauna including rodents, bats, birds, lizards, anurans, and birds, in addition to other organics such as charcoal and seeds in a poorly sorted sandysilt matrix with abundant angular limestone gravels. The time-averaging represented by these deposits has yet to be calculated but is likely in the order of decades. Preliminary examination of this material suggests deposition from avian predators; however the presence of Sus scrofa amongst the remains indicates some anthropogenic input.

West of MK1 is a small side passage in a moderatelysized cave which yielded the first unambiguously Middle Pleistocene fossil record for Timor-Leste (Matja Kuru TD). This side chamber actually consists of two separate depositional sequences in reverse stratigraphic position. The chamber is L-shaped and predominately north-south in orientation. Its longest arm measures approximately $6 \mathrm{~m}$ in a northerly extension, and was approximately $1.5 \mathrm{~m}$ wide and $1 \mathrm{~m}$ high prior to excavation. It is accessed by an approximately $120 \mathrm{~cm}$ inclined, westerly passage with 
an east-facing opening approximately 40 × $60 \mathrm{~cm}$ wide, located on the western wall of, and approximately $2 \mathrm{~m}$ past, the main cave entrance. The floor of the chamber was formed from a thin, horizontally bedded speleothem crust. Beneath this crust a dissolution basin was excavated in $15 \mathrm{~cm}$ spits to a maximum depth of $65 \mathrm{~cm}$. The sedimentary sequence consisted of massive, poorly sorted unconsolidated silts and muds, with abundant clay pisoids and well preserved faunal remains, including complete and near-complete cranial and postcranial elements of extinct giant rats, modern rodents, bats, birds, lizards, snakes, and small numbers of fish and turtle remains. The clay pisoids are up to $10 \mathrm{~mm}$ in diameter; they are nucleated but not concentrically laminated (Fig. 6g) and make up more than $10 \%$ of the clasts. Other clasts included angular autogenic limestone gravels and sands. A dissolution vugh in the surface crust (Fig. 6h) returned a ${ }^{230} \mathrm{Th}$ age of ca. $10 \mathrm{ka}$ (Table 2). Two straw stalactites from the top $15 \mathrm{~cm}$ of the deposit returned ages of ca. 8.1-8.2 ka, while two additional straws from $30-45 \mathrm{~cm}$ in depth returned ages of 6.9-7.0 ka. Two giant rat incisors, one from the top $30 \mathrm{~cm}$ of the deposit (TD-1), and the other from 30-45 cm depth (TD-2) were serially dated. Both provided reliable, though stratigraphically inverted ages if these ages are interpreted as close to their real age: TD- 1 is ca. $17.5-18 \mathrm{ka}$ and TD-2 is $5.5 \mathrm{ka}$; and a minimum age of $\sim 18 \mathrm{ka}$ if both are considered coeval. A flowstone sample, taken approximately $15 \mathrm{~cm}$ below the floor crust and forming part of the wall of the basin hosting the assemblage constrains the maximum age of deposit of ca. $205 \mathrm{ka}$ (Table 2). The presence of clay pisoids in the assemblage, many with isolated teeth and bone fragments forming the nuclei, suggests deposition in a very low energy, probably ephemeral shallow-water environment. This is supported by the complete and near complete postcranial elements of the giant rats, which show little to no surface modifications from significant postdepositional movement. However, some reworking of the deposit is suggested by the older ages calculated from the overlying speleothem crust relative to the ages of the underlying fossils and straw stalactites. The following depositional history is suggested for this deposit: sometime after $205 \mathrm{ka}$ the basin filled with sediment and became phreatic. A calcite crust formed at the contact between the phreatic and vadose zones $\sim 10 \mathrm{ka}$. The water table subsequently dropped and the majority of the underlying unconsolidated sediment eroded out, creating a false floor. At approximately $7 \mathrm{ka}$, fossil-rich sediments incorporating older $(\sim 18 \mathrm{ka})$ fossils travelled from a low-energy water source proximal to the basin and refilled this cavity.

While excavating the lower deposit, a thin but horizontally extensive fossil-bearing breccia was observed along the west wall approximately $50 \mathrm{~cm}$ above the floor crust. Bone and terrestrial molluscs were observed eroding out, and subsequent processing in acetic acid produced giant and normal-sized rats, bat, and other microfaunal remains. This breccia was clay-rich and pisolitic, with numerous clay pisoids recovered after acid preparation indicating minimal to no carbonate component to the clay. We attempted radiocarbon dating on several charcoal samples from this breccia but these did not survive pre-treatment. Identical to the younger deposit in the chamber, isolated teeth and bone fragments formed some of the pisoid nuclei, although detrital grain nuclei were more numerous. The poorly sorted nature of the original deposit was preserved and lithified by calcite cement, and no spatial associations or orientations were observed between the angular to sub-angular limestone clasts, the fossils, and pisoids (Fig. 7). An underlying flowstone produced a date of ca. $165 \mathrm{ka}$ (Table 2). Due to the presence of gypsum crystals, numerous clay pisoids, terrestrial molluscs, angular limestone gravels, and the random orientation of the clasts, we infer that this deposit formed in a very low energy, ephemeral shallow-water environment similar to the younger deposit described above.

\section{Sumatra}

The scientific exploration of caves in Sumatra dates to the end of the $19^{\text {th }}$ century when Dubois started searching for hominins in Asia (Dubois, 1891). Dubois targeted caves in the Padang Highlands of western Sumatra, and we surveyed a total of 25 caves in that area for vertebrate deposits, including at least one previously excavated by Dubois (Lida Ajer). The Sumatran caves were generally large, complex, multi-chambered anastomotic solutional caves (Fig. 8), although some graded into joint-controlled network caves. The caves largely occurred in tower karst surrounded by poljes that have been heavily agriculturalised. Non-fossiliferous breccias were commonly encountered, and high energy phreatic environments were recorded for several caves. Of the caves surveyed, five preserved fossils, although two preserved only a single tooth fragment in an otherwise barren breccia. In one additional cave we observed an active porcupine den with large mammal surface bone deposits (Fig. 8). The almost complete lack of microfaunal surface deposits in Sumatran caves was striking, with only one rat mandible observed on the surface of a narrow tunnel near the entrance of Ngalau Sampit during the three week survey. Here we focus on the three main fossil-bearing caves recorded. With only one exception, all fossils observed in the Sumatran breccia deposits consisted of isolated teeth of large mammals, most of which only preserved tooth crowns. Evidence of gnawing on the teeth was common.

Ngalau Lida Ajer is a small cave consisting of two main chambers, the rear one of which preserves four discrete breccia deposits, probably belonging to the same depositional event. The breccia is characterised by large, angular, allogenic clasts, isolated mammal teeth including orangutan, porcupine, and tapir, and a cemented, poorly-sorted sandy clay (Fig. 8a), which in some exposures approaches a diamictitic facies. The deposits have undergone secondary erosion and they are largely preserved as relict cave fill on the walls of the chamber, overlain by flowstone. Flowstone also underlies the breccia found in the middle of the chamber. The flowstones associated with 

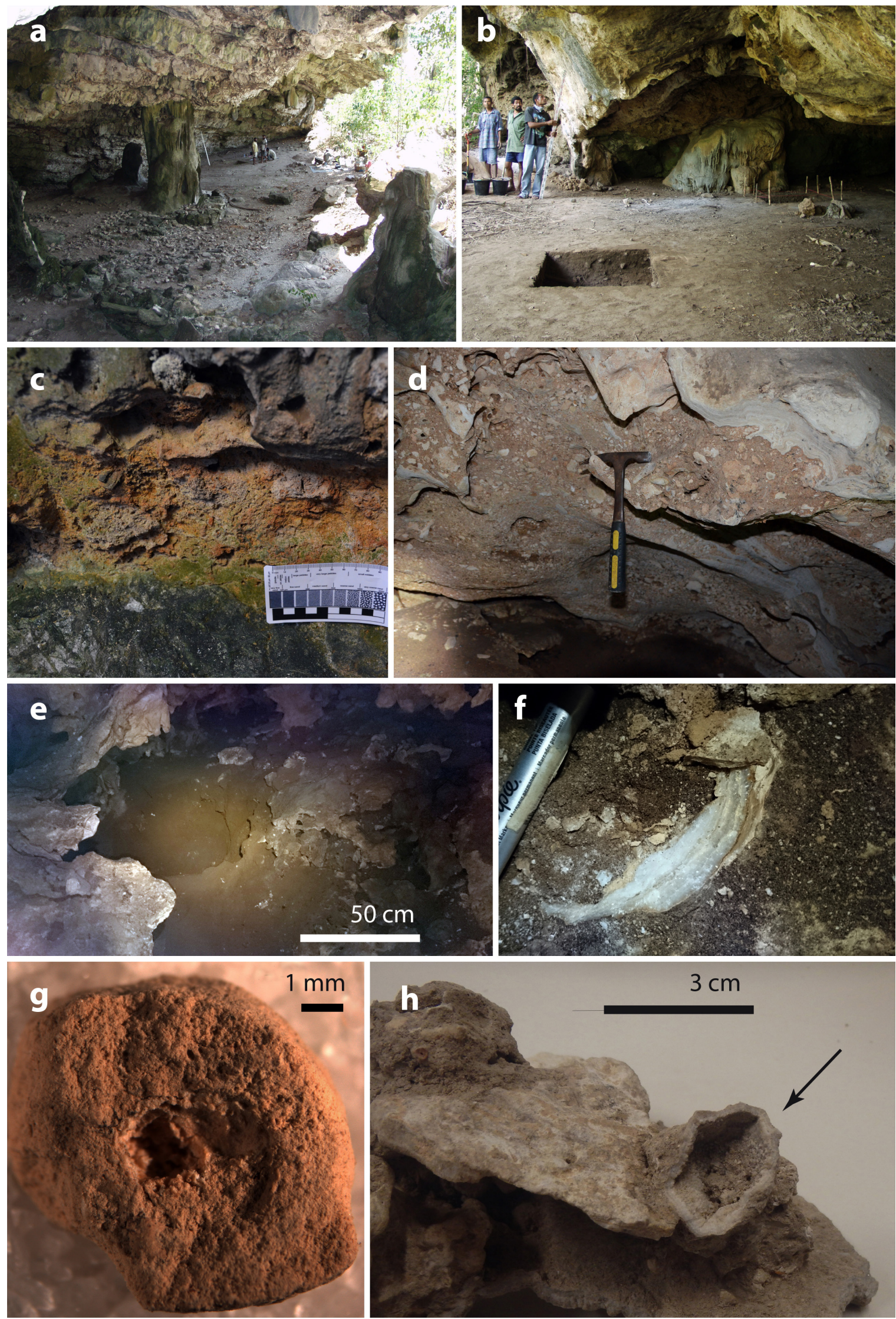

Fig. 6. Timor Island. a) Lene Hara Cave, showing large central pillar under which a breccia was recorded; b) Jerimalai Cave; c) fossil free breccia in Fatu Aki Ani Knua cave; d) Gua Monyet breccia; e) Matja Kuru TD excavation; f) flowstone forming the base of the Matja Kuru TD deposit; g) cross section of a clay pisoid from the Matja Kuru TD deposit; h) capping flowstone and dated vugh (indicated by arrow) of the unconsolidated Matja Kuru TD deposit. 
₹

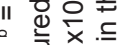

言总品怘

을

뜬요 "⿻

o 8 通

要

o잉

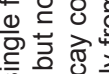

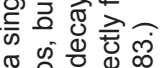

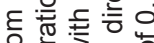

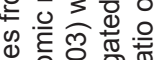

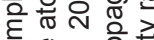

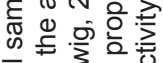

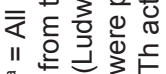

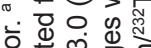

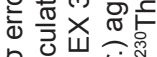

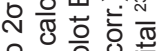

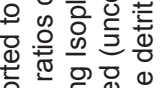

휸.

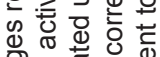

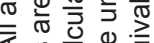

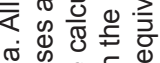

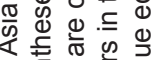

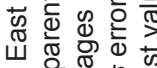

吏.

क응

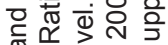

क

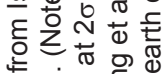

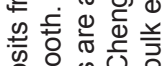

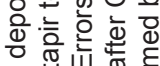

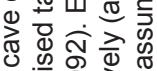

व

过

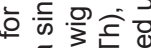

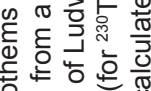

क्ष

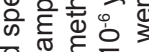

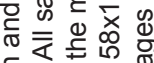

๘ี

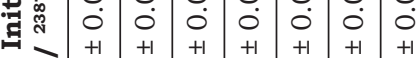

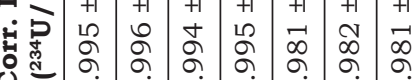

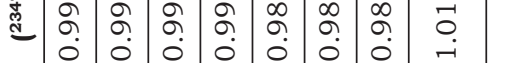

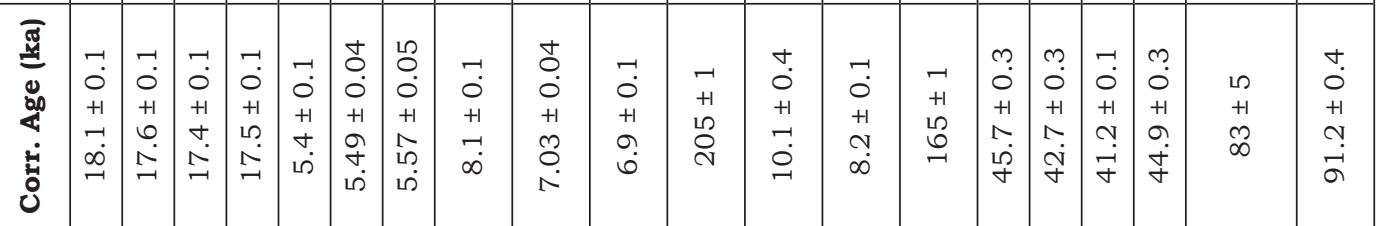

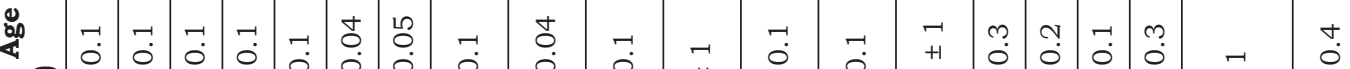

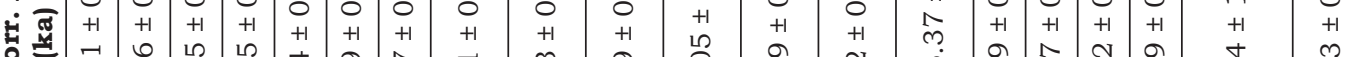

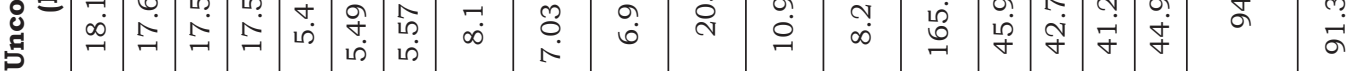

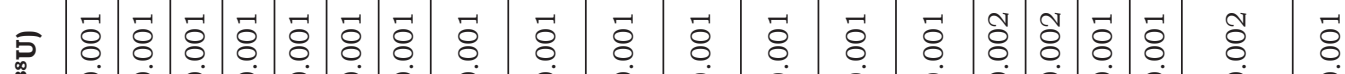

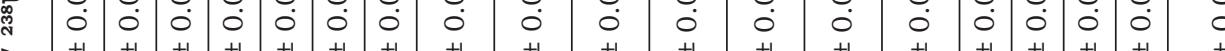

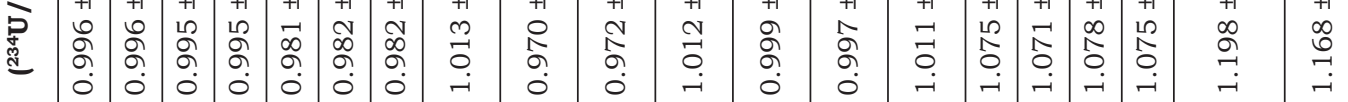

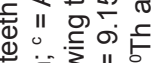

市至

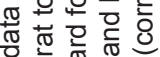

ᄃ응 $\frac{\pi}{\circ} \stackrel{0}{5}$

\begin{tabular}{|c|c|c|c|c|c|c|c|c|c|c|c|c|c|c|c|c|c|c|}
\hline $\begin{array}{l}\overrightarrow{0} \\
0 \\
0 \\
0 \\
1 \\
0 \\
10 \\
0 \\
0\end{array}$ & $\begin{array}{c}\overrightarrow{0} \\
0 \\
0 \\
+1 \\
o \\
g \\
\dot{0} \\
\dot{0}\end{array}$ & $\mid \begin{array}{c}0 \\
0 \\
0 \\
+1 \\
\hat{+} \\
\dot{+} \\
\dot{0}\end{array}$ & $\begin{array}{l}\overrightarrow{0} \\
0 \\
0 \\
+1 \\
+ \\
\dot{+} \\
\overrightarrow{0}\end{array}$ & 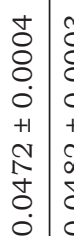 & 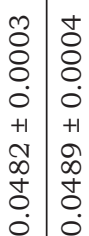 & $\begin{array}{l}+ \\
8 \\
0 \\
0 \\
0 \\
+1 \\
\vec{N} \\
\hat{N} \\
0 \\
0\end{array}$ & $\begin{array}{l}0 \\
8 \\
0 \\
\dot{0} \\
+1 \\
0 \\
0 \\
0 \\
0 \\
0\end{array}$ & $\begin{array}{l}+ \\
0 \\
8 \\
0 \\
0 \\
+1 \\
\hat{0} \\
0 \\
0 \\
0 \\
0\end{array}$ & $\begin{array}{l}\mathcal{\delta} \\
0 \\
\dot{0} \\
+1 \\
0 \\
0 \\
\infty \\
\infty \\
0\end{array}$ & $\begin{array}{l}0 \\
8 \\
0 \\
0 \\
+1 \\
+ \\
o \\
0 \\
0 \\
0 \\
0\end{array}$ & 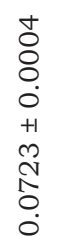 & 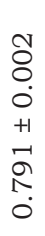 & $\begin{array}{l}0 \\
0 \\
0 \\
0 \\
+1 \\
\vec{A} \\
0 \\
0 \\
0\end{array}$ & $\begin{array}{l}0 \\
0 \\
0 \\
0 \\
+1 \\
o \\
+ \\
m \\
0 \\
0\end{array}$ & $\begin{array}{l}\overrightarrow{8} \\
0 \\
0 \\
+1 \\
\vec{y} \\
0 \\
0 \\
0\end{array}$ & $\begin{array}{l}0 \\
8 \\
0 \\
0 \\
+1 \\
0 \\
0 \\
0 \\
0 \\
0\end{array}$ & $\begin{array}{l}0 \\
8 \\
0 \\
+1 \\
0 \\
\stackrel{1}{1} \\
\vdots\end{array}$ & $\begin{array}{l}\dot{0} \\
+1 \\
+\end{array}$ \\
\hline
\end{tabular}

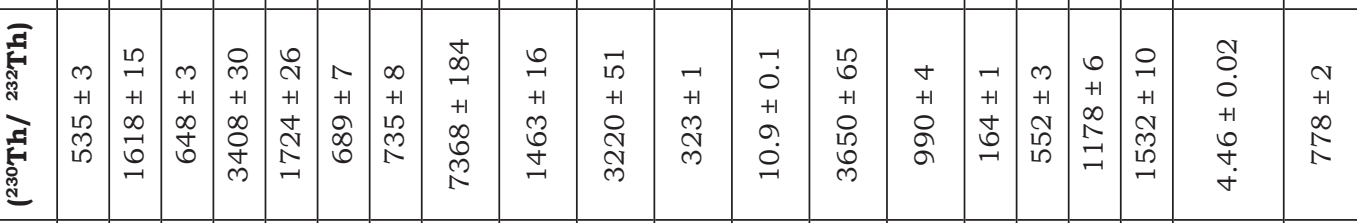

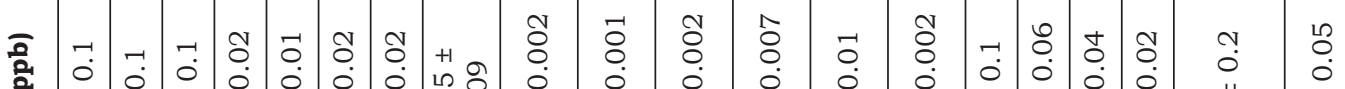

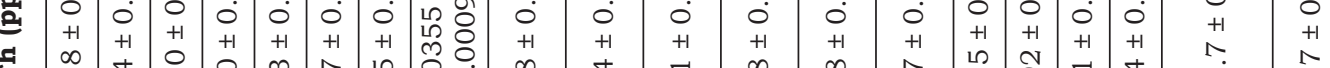

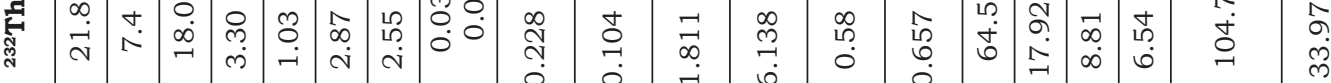

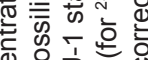

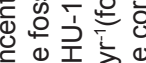

要

둥

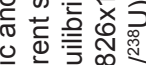

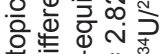

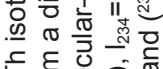

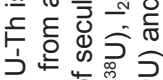

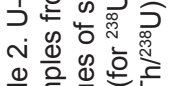

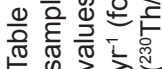

\begin{tabular}{|c|c|c|c|c|c|c|c|c|c|c|c|c|c|c|c|c|c|c|c|c|}
\hline & $\begin{array}{l}\overrightarrow{0} \\
0 \\
0 \\
+1 \\
\vec{N} \\
\stackrel{\rho}{\rho} \\
\stackrel{n}{n}\end{array}$ & 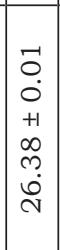 & 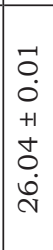 & $\begin{array}{l}\overrightarrow{0} \\
0 \\
0 \\
+1 \\
0 \\
0 \\
\dot{\rho} \\
\stackrel{d}{N}\end{array}$ & 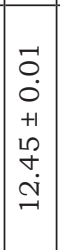 & 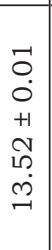 & $\begin{array}{l}-\overrightarrow{0} \\
0 \\
0 \\
+1 \\
+ \\
0 \\
0 \\
\dot{j} \\
-1\end{array}$ & 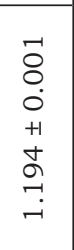 & $\begin{array}{l}\overrightarrow{8} \\
\dot{0} \\
0 \\
+1 \\
\overrightarrow{-1} \\
\stackrel{0}{-}\end{array}$ & 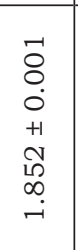 & \begin{tabular}{l}
$\overrightarrow{0}$ \\
8 \\
0 \\
0 \\
+1 \\
$\overrightarrow{+}$ \\
\multirow{N}{*}{} \\
0 \\
0
\end{tabular} & 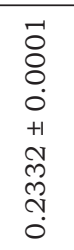 & \begin{tabular}{l}
8 \\
0 \\
$\vdots$ \\
0 \\
+1 \\
+1 \\
\multirow{1}{0}{} \\
0 \\
$\dot{0}$
\end{tabular} & 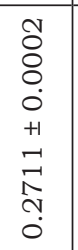 & $\begin{array}{l}0 \\
0 \\
0 \\
0 \\
+1 \\
0 \\
\infty \\
0 \\
\sigma \\
0\end{array}$ & 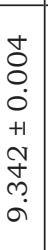 & $\begin{array}{l}0 \\
0 \\
0 \\
0 \\
+1 \\
\infty \\
\tilde{~} \\
0 \\
\dot{0}\end{array}$ & $\begin{array}{l}+ \\
0 \\
0 \\
0 \\
+1 \\
0 \\
0 \\
0\end{array}$ & 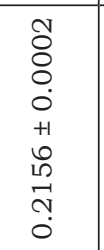 & 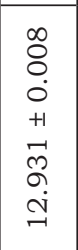 \\
\hline & & 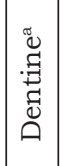 & & 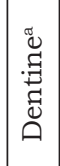 & 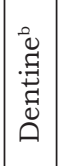 & 口 & 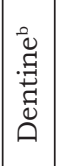 & 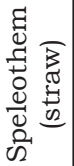 & 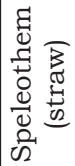 & 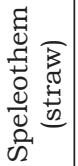 & 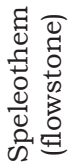 & 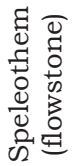 & 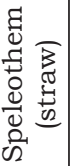 & 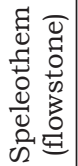 & & & & & 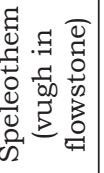 & \\
\hline
\end{tabular}

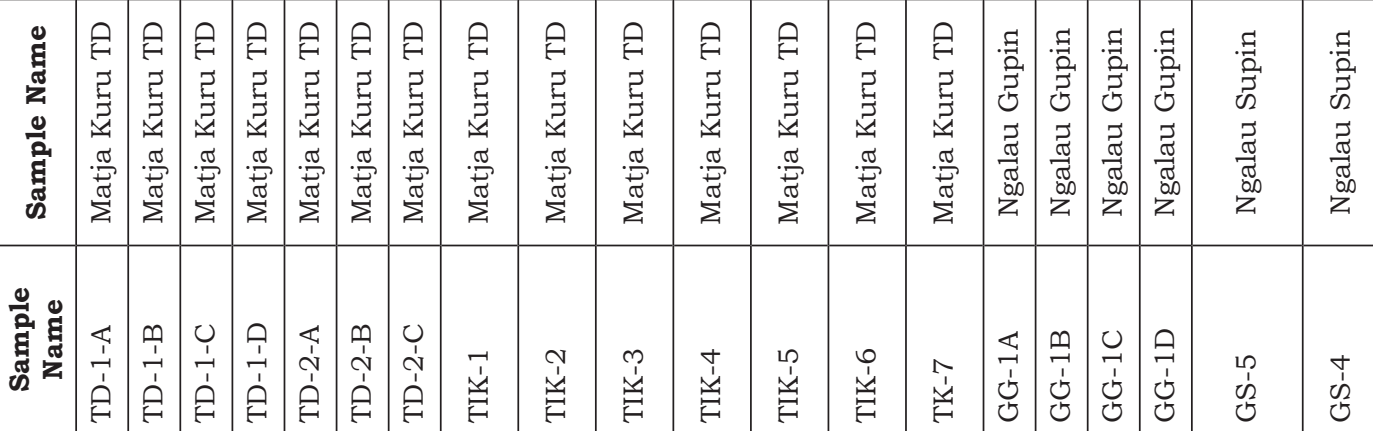




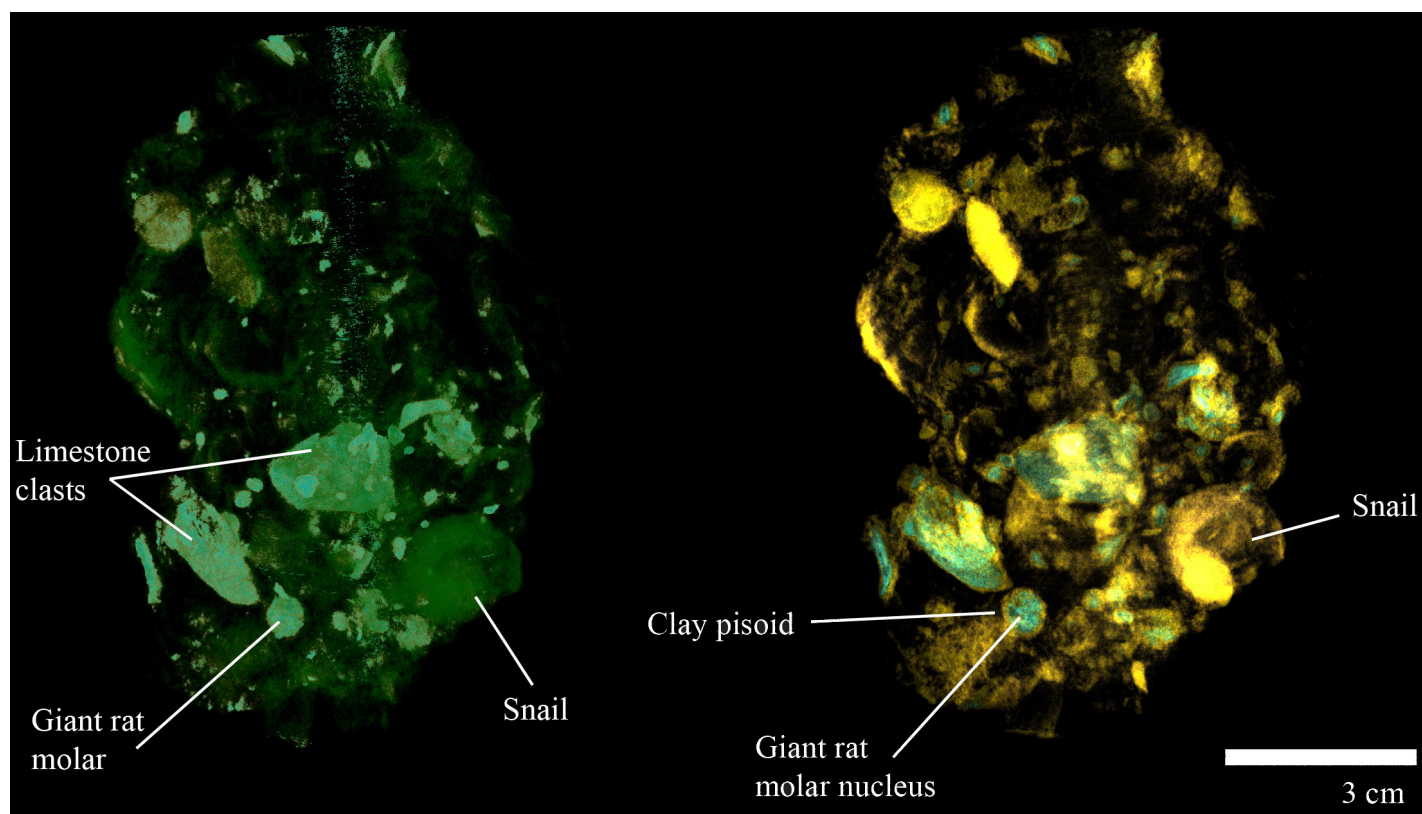

Fig. 7. Two false-colour volume rendered neutron computed tomography images of a Matja Kuru TD breccia subsample, each coloured and filtered to highlight the different clasts and inclusions.

these deposits have high detrital allogenic particle content, giving them a darkened 'dirty' appearance, and indicating sediment influx during speleothem formation. Detailed geochronological analysis of these deposits indicate a Late Pleistocene age (Westaway et al., 2017); younger than, but close to, ages suggested by relative dating of teeth from the Dubois legacy material using amino acid racemization (Drawhorn, 1994). A sinkhole at the rear of the chamber branches into two small blind tunnels. Both tunnels are formed in a diamicton consisting of unlithified clays and muds with suspended isolated teeth from extant mammals including pig, orangutan, and rhinoceros. A nearby cave, Ngalau Unjo, also produced breccia and fossil deposits. In the breccia deposit, an isolated cervid tooth in an otherwise massive cemented breccia was observed. Unlike Lida Ajer, large angular clasts were not observed. Two isolated surface pig teeth were recovered from a nearby chamber which appeared mineralised and reworked, suggesting erosion from a previously lithified deposit. Likewise, the cave Ngalau Indah preserved only a single rhinoceros tooth fragment in a poorly sorted breccia deposit. Unlike Ngalau Unjo and Ngalau Lida Ajer, this breccia consisted of an amorphous speleothem matrix with many angular autogenic limestone clasts, and on the basis of this is likely a product of solution brecciation processes, with the inclusion of a tooth fragment a serendipitous event.

Ngalau Sampit is a large cave complex, only partly surveyed. Both vadose and phreatic zones were present in the explored chambers. Fossils are preserved in lithified to semi-lithified breccia with intercalated flowstones on the northern and southern ends of a small side tunnel abutting a much larger dissolution chamber found by traversing three narrow passages with a total length of approximately $30 \mathrm{~m}$. The breccia deposit consists mostly of isolated teeth including bovid, orangutan, cervid, pig, and porcupine, in addition to large, angular, allogenic clasts in a pitted, speleothem matrix. Unusually for Southeast Asia, a partial cranium of an ungulate is also preserved on the roof of the eastern part of the chamber (Fig. 8b), which tapers, doglegging after approximately $2.4 \mathrm{~m}$, and terminating shortly after. U-Th dating of a capping flowstone in the western, larger $(2 \times 1.7 \mathrm{x}$ $3 \mathrm{~m})$ sub-chamber terminal of the tunnel produced an age of ca. $91 \mathrm{ka}$. This minimum age is supported by a date of $83 \pm 5 \mathrm{ka}$ for a calcite-filled vugh within the breccia (Fig. 8e). Secondary erosion of both deposits is evident, and extensive post-depositional flowstone indicates considerable water movement in the chamber following the brecciation event.

Ngalau Gupin is also a large cave complex with a breccia deposit in a small side sub-chamber (Fig. 8). Unlike Ngalau Sampit, Ngalau Gupin preserves no datable flowstone; however, U-Th dating of a Tapirus molar has produced a reliable minimum age of $\sim 45 \mathrm{ka}$. On the basis of ${ }^{230} \mathrm{Th}$ age and U-concentration profiling, the tooth appears to have taken up $U$ rapidly following burial, and it is possible that the resulting ages approximate the true age of the tooth (Fig. 8g). Ngalau Gupin hosts a modern fauna including porcupine, pig, monkey, elephant, bovids, cervids, rhinoceroses, and viverrids recorded from initial spot collection of isolated teeth. These occur alongside terrestrial molluscs which are large, angular allogenic and autogenic clasts, lightly lithified within clay-rich matrix. It occurs as a discrete deposit on the northern end of the side sub-chamber, however a small smear of breccia on the southern end of this sub-chamber indicates the breccia was likely more extensive in the past. Surface teeth with adhering matrix and the same preservation, collected next to the sub-chamber, suggest secondary erosion of the breccia.

\section{Discussion}

The caves surveyed fell into several developmental and geological types. Volcanic caves were observed on Sangihe, Alor, and Pantar. Volcanic caves were almost always produced as a result of subaerial mechanical and hydrological weathering, although important 
exceptions are the lava tube caves recorded on Alor. Limestone caves were observed on Talaud, the Kabola peninsula of Alor, small, isolated patches on Pantar, Timor, and Sumatra. The niches observed on Pantar and the south coast of Timor are likely tafoni caves, formed by subaerial chemical and mechanical weathering. All other limestone caves represent dissolution caves. Several, such as the large cave complexes on the east coast of Timor-Leste (e.g., Lene Hara, Matja Kuru), and possibly some of the smaller caves on Talaud and the Kabola peninsula of Alor, are likely flank-margin caves and thus, after factoring in local uplift, would be indicative of previous sea level highstands (e.g., Mylorie \& Mylorie, 2009).

\section{Accumulation - geological factors}

The effect of geology on the preservation of vertebrates falls into three broad categories: lithology of the host rock, age of the host rock, and diagenetic processes. In many of the small, isolated islands in Wallacea, the dominant lithology is volcanic, with smaller amounts of metamorphic and sedimentary deposits recorded; the latter largely restricted to coastal limestone deposits. With the exception of volcanic lava tubes, the caves that had formed in volcanic rocks were almost always small, shallow, single-chambered cavities grading to overhangs that have been used as rockshelters. Biotic autochthonous processes are largely non-existent in such caves, and abiotic allochthonous vertebrate depositional events are incredibly rare. On the other hand, biotic allochthonous processes were observed in several instances in these caves through the actions of raptors (particularly owls) and people. Long-term preservation of such remains is unlikely because: 1) sediments in volcanic caves are often acidic and not conducive to bone preservation; 2) the open and shallow cave systems means sediments are highly subject to extreme erosional events (evidenced by several, largely sediment-free floors observed; e.g., Fig. 3); and 3) volcanic caves generally lack soluble minerals, such as carbonates, which could cement and preserve vertebrate remains.

Where limestone is present on these isolated islands, it is restricted to the coast and is at most only a few hundreds of thousands of years old. The caves formed therein are commonly small, ramiform to spongework, with few chambers and are formed in highly porous, coralline limestone. The size and shapes of these caves make them generally unattractive to roosting raptors and because the limestone is so young and coastal, deep and complex caves with numerous passages and dark zones have not had a chance to form, restricting the number of cavernicolous mammals and the degree of speleothem formation. The latter is because young, laterally restricted, spongework caves with few passages afford limited time and surface area for carbonic acid to dissolve carbonates. In turn, this reduces the volume of supersaturated water travelling through the cave system, as well as the potential for exposure to cave air for carbon dioxide exchange, and thus carbonate precipitation. Furthermore, only deep, mature caves have passages that act as active conduits for water flow and sedimentation, and provide potential sources of recharge.

Thus, geological factors inhibit many of the vertebrate accumulation processes outlined by Simms (1994) on small, largely volcanic islands of Wallacea. Vertebrate accumulation and preservation on such islands are instead largely driven by stochastic processes and dependent on unusual geological conditions. On the other hand, the larger, older, and geologically more complex islands such as Sumatra and Timor host deep, network to anastomotic caves with many phreatic and vadose passages. Most of these were observed in massive limestones with large areal exposures several millions of years old, and with extensive and various speleothem deposits. Evidence for biotic autochthonous vertebrate deposits is restricted to bat remains; however, these were made possible by the many dark zones present in the large caves that bats tend to frequent. Because of the long and complex speleogenesis evident in many Sumatran and Timorese caves, possible abiotic allochthonous accumulations related to transportation by fluvial events were observed. Several breccias had abundant large, allogenic clasts, and the inclusion of allogenic vertebrate material in such breccia is likely though not yet demonstrated. These examples notwithstanding, evidence for abiotic processes controlling primary vertebrate accumulation was rare even in the oldest caves explored, and no pit-fall traps were recorded.

\section{Accumulation - biotic factors}

Biogeographical conditions in Southeast Asia limit the agents of accumulations for faunal remains in caves. The small, isolated islands of Nusa Tenggara have low biodiversity, with vertebrate trogloxenes represented by owls, swallows, anurans, reptiles, bats, and rats. All these taxa can contribute faunal remains directly when dying in a cave; however, this rarely produces significant accumulations of skeletal material. Snakes and lizards commonly feed on other vertebrates in caves, although these actions rarely leave any identifiable remains. Small rodents have been known to carry skeletal elements into and around caves (Lyman, 1994), but evidence for this has rarely been observed for any of the Wallacean assemblages we have examined. Thus, the depauperate, endemic terrestrial faunal communities on isolated islands in the region have produced no species likely to transport significant numbers of faunal remains into caves. In small and isolated islands, once geological factors are accounted for, the only significant accumulator of natural bone deposits in caves are owls.

Conversely, microfaunal deposits were incredibly rare in our survey of the Sumatran caves. There, the only natural surface bone accumulation observed was a porcupine den. Porcupines are commonly implicated as accumulators of faunal materials in caves throughout Southeast Asia, with resulting deposits throughout the region typically represented largely if not exclusively by isolated teeth of various taxa (Lenoble et al., 2006; Duringer et al., 2012). Porcupines are renowned collectors of large numbers of dry bones scavenged from areas surrounding caves 
(e.g., Brain, 1981, O’Regan et al., 2011; Bountalis et al., 2014). They gnaw these bones to hone their teeth, for osteophagia, or to prevent botulism, leaving distinctive gnaw marks on bone surfaces (Bountalis et al., 2014). The Cape porcupine Hystrix africaeaustralis, for example, is an indiscriminate collector, accumulating bones of species of body mass ranging from $>0.14 \mathrm{~kg}$ to $<940 \mathrm{~kg}$ (O'Regan et al., 2011). Elements collected by this species range from isolated bovid phalanges to entire crania, and the percentage of a gnawed bone can range from 93.6 to $54.6 \%$, with larger bones seemingly preferred
(O'Regan et al., 2011). Southeast Asian fossil deposits, however, contrast markedly from other regions in being comprised almost exclusively of teeth and tooth crowns. Whether this pattern reflects a dearth of bones on the landscape in Pleistocene Southeast Asia (fewer bones on the landscape will result in more gnawing of collected bones: Brain, 1981; Lyman, 1994), or is a result of further taphonomic processes has not been adequately assessed. However, our discovery of bone shafts in a modern porcupine assemblage in Sumatra (Fig. 8f) suggests the latter likely played a role.
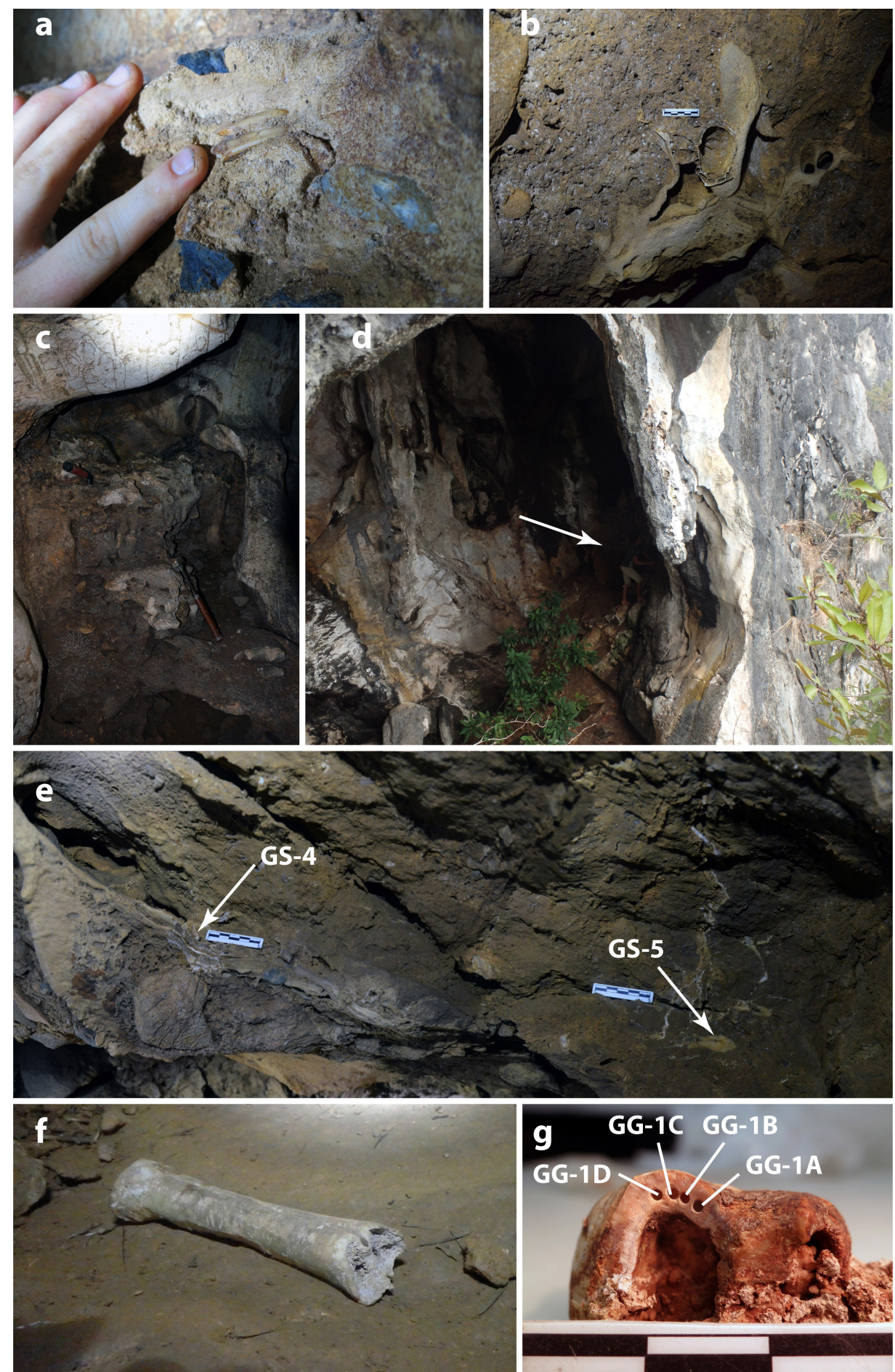

Fig. 8. Sumatra. a) Lida Ajer breccia showing bovid tooth eroding out; b) Ngalau Sampit breccia, with unknown skull eroding out from the wall; c) Ngalau Gupin breccia; d) Ngalau Agung Agung, a large dissolution cave of high elevation, arrow indicates person for scale; e) Ngalau Sampit dating samples: GS-4 is a capping flowstone over the breccia, GS-5 a calcite filled vugh f) gnawed metapodial found in an active porcupine den in Ngalau Kamang; g) tapir tooth from Ngalau Gupin showing drill holes for U-Th dating. 
While it's possible that any putative microfaunal deposits in Sumatra were later destroyed by porcupines, Sumatra is also home to several smallto medium-sized carnivorous species that may consume microfauna, accounting for the few remains observed. However, it is more likely that the highly urbanised and agriculturally concentrated regions that we surveyed, in combination with more intensive cave use by local villagers and unsustainable owl harvests for the novelty pet market (e.g., Shepherd, 2006), have resulted in significantly reduced raptor numbers in Padang, with concomitant reductions in active raptor roosts. The number of sites producing terrestrial microfaunal remains in surface deposits in Sumatra ( 4\%) could be close to the rate expected from natural deaths in the absence of avian predators. The likelihood of long term preservation and subsequent discovery of such remains is miniscule. Other than porcupines, Sumatra also hosts several taxa that conceivably could bring faunal remains into caves, in particular large carnivores such as the tiger and the now extinct Sumatran leopard. However, none of Sumatra's known large carnivores are known to normally occupy caves or use them for stashing kills, making it unlikely they have contributed significantly, if at all, to vertebrate remains in caves. Hyenas have not yet been reported from Sumatra's fossil record, however, they are commonly recovered in many sites throughout Southeast Asia (Louys, 2014), where they are likely to have contributed to the accumulation of faunal remains in caves. Likewise, humans have also had a long history of cave use in Southeast Asia.

In fact, it seems likely that very soon after humans arrived in a given region, they made use of caves, either periodically or as permanent home bases. Archaeological sites, particularly on the small isolated islands of Wallacea, represent the most reliable source of vertebrate remains in caves. Human refuse, in the form of burnt, cut-marked, and/or chewed skeletal elements, provided abundant faunal remains in the caves we explored. Moreover, commensal species such as rats, probably drawn by the refuse, were regularly encountered. The most common vertebrates recovered from coastal caves and rockshelters were marine organisms, in particular reef fishes (O'Connor et al., 2011; Samper Carro et al., 2016). More inland, marine organisms become obviously less common in archaeological deposits, replaced by birds, reptiles, and large rodents (Glover, 1986; O'Connor \& Aplin, 2007).

\section{Preservation}

Long term preservation of vertebrates is largely dependent on rapid burial following surface deposition. In caves, burial is facilitated by sedimentation, with water being the dominant transportation agent of sediment undergoing lateral movement underground (Farrant, 2004). Like fluvial sequences, whether sedimentation or erosion occurs is subject to the energy of the water movement, but in caves it is also a function of passage morphology, with boulders and fine cohesive clays the most resistant to reworking (Gillieson, 2004). Thus, vertebrate remains, being essentially large clasts, are prone to movement in caves, particularly during flooding and mass movement events. However, steep energy gradients in cave passages, a result of variable flood events and the geometry of the passage (Gillieson, 2004), localises erosional events and can result in translocation of clasts not far from their source. Within a cave, sediments and fossils can be deposited in a single, fluidised, self-perpetuating sliding mass, resulting in deeply penetrating "sliding bed" facies; a result of pipefull conditions or mass movement events (Farrant, 2004). Such facies have been recorded for the karstic caves of New Guinea (Gillieson, 1986) and some of the sedimentary units in Niah Caves, Borneo (Gilbertson et al., 2013), and they are likely responsible for the massive, poorly sorted, allogenic clast-rich diamictites and diamictons observed in some of the Sumatran caves we examined.

Cave entrances can experience significant rates of sedimentation due to human activity. The introduction of sediment from people, either from adhering mud, vegetation, refuse, and animal matter, and/or fires can significantly increase sedimentation rates. For example, Farrand (2001) reported sedimentary accumulation at a rate of as high as $250 \mathrm{~cm}$ per 100 years in Mesolithic deposits in Franchthi Cave, Greece. Human activity was identified as a major driver and contributor of sediment accumulation at the cave entrances of both Lene Hara and Laili, significantly impacting local slope stability and dominating the allochthonous sedimentary input (O'Connor et al., 2016); a process similarly observed in Jerimalai, MK1, 2, Tron Bon Lei, Makpan, and Fatu Aki Anik Knua. Thus, in addition to being a major vector for the introduction of vertebrates into caves, human activities significantly favour their longer-term preservation potential by increasing sedimentation rates near entrances and altering cave entrance topographies such that subsequent erosion is minimised.

However, longer-term preservation of vertebrates in caves is almost entirely dependent on rapid burial and subsequent lithification, usually with carbonate cements. The geochemical processes controlling carbonate precipitation and speleogenesis in caves is relatively well understood. Water in cave systems can become supersaturated with respect to calcite as a result of dissolution of limestone from weak carbonic acids produced in overlying soils. When the supersaturated $\mathrm{H}_{2} \mathrm{O}-\mathrm{CO}_{2}-\mathrm{CaCO}_{3}$ solution degasses carbon dioxide, usually when exposed to cave air, calcite is precipitated (Fairchild \& Baker, 2012). Speleothems form from a variety of different water regimes: flowing, dripping, pool, seeping, and condensation waters, or a combination (Hill \& Forti, 2004). In lacustrine settings, carbonate cementation occurs at the sediment-water interface (Chafetz et al., 1985). The rate of carbonate precipitation is controlled by many factors including the chemistry of the solution, the volume to surface-area-of-precipitation ratio, and the hydrodynamic flow conditions, but in general is higher in faster flowing waters (Dreybrodt, 2004). Precipitation of carbonates from 
supersaturated solution can also result from biogenic processes. For example, algae and bacteria have been known to induce mineralisation of carbonates by drawing out $\mathrm{CO}_{2}$ from solution (Shopov, 2004). While the former will only be active in the entrance and twilight zones of a cave, presumably bacteria could be active throughout the cave system, and particularly associated with decaying organic material. While speleogenic processes are relatively well-understood, a general lack of studies dealing with the cementation of faunal remains into breccias in caves is surprising. Generalisations are probably not possible due to the idiosyncratic nature of individual breccia formation events, but nevertheless, even isolated case studies of the cementation process involving vertebrate remains could not be found (possible exceptions are the studies examining cementation of hearths, ash, and other sediments in archaeological settings; see Shahack-Gross et al. (2008) and Villagran et al. (2016) for example). Thus, it is not possible to know to what extent carbonate precipitation from bacterial action contributes to vertebrate breccia formation, if at all.

In our surveys, we observed three notable types of vertebrate-rich breccia. The first, represented by the diamictic breccias of Ngalau Lida Ajer, Ngalau Sampit, and Ngalau Gupin, were characterised by a lithified to semi-lithified mud matrix with large, angular allogenic clasts, and isolated vertebrate remains, almost exclusively isolated teeth. We consider these to have formed in mass movement events in the cave precipitated by prolonged rainfall and earthquakes analogous to events described by Gillieson (1986). In this instance, we suggest lithification was probably a result of seeping supersaturated solution through porous muds, evidenced in at least one breccia by the presence of vughs. Taphonomically, deposition by mass movement events may not produce gross transportation damage on skeletal elements if the sediment is completely fluidised and there are a small number of clasts relative to the amount of finergrained matrix.

The second type of breccia observed is characterised by clay matrix with abundant clay pisoliths, disarticulated but largely undamaged skeletal elements, and complete terrestrial gastropod shells (e.g., the pisolithic breccia of Matja Kuru TD). In this instance, it is suggested that initial deposition occurred in a low energy, ephemeral pool or basin, allowing clay accumulation and pisoid formation. Subsequent lithification was likely at the sedimentwater interface in a low energy environment, and as such would have been largely coeval with deposition. The third type of breccia is represented by the archaeologically significant breccias of Lene Hara and Laili, and already described in detail by O'Connor et al. (2016). These breccias are characterised by the inclusion of archaeological material and formation at or near cave entrances. While algal and bacterial precipitation of carbonate has yet to be ruled out for cementation, given the extensive speleothem formations associated with the Lene Hara breccia, it is more likely that dripping water onto cave floors cemented these deposits in situ. Such processes have the potential to also act on surface owl roost deposits; however, no examples of such breccias were recorded in our surveys. O'Connor et al. (2016) further suggested that brecciation and speleothem deposition in the caves they examined were intimately associated with and may have been coupled to regional climatic trends. Whether this hypothesis can be generalised for the entire region and all types of breccia requires further examination.

Contrary to initial expectations, the likelihood of brecciation was not found to be a function of the age of the host caves. In other words, we expected that breccia deposits would most likely be found in older cave systems with well-developed passages, older host limestone, and associated with faunal remains that were Pleistocene in age. However, as the example of human-bearing breccia at Gua Tahirang demonstrates, cementation of faunal remains can occur even in very young caves, and quite rapidly provided the right environmental conditions are met. The Gua Tahirang example is not an isolated case of quick cementation: human remains have also been recorded from a breccia in Gua Andamo in Sulawesi dated to $\sim 1,000$ cal BP (Oktaviana et al., 2016). This suggests that the overriding limiting factor in vertebrate-bearing breccia formation is not the age of the cave system, but rather the presence of faunal remains to cement.

Breccia formation in all the caves surveyed was most likely facilitated by water movement in the cave (as opposed to actions of microorganisms), and can be evidenced by associated and extensive speleothem formation in each system producing breccia. Paradoxically, the conditions that favour thick and rapid flowstone growth - fast-flowing water - are also those that probably contribute most to erosion of sediment. Other water regimes in caves can also result in erosional events that destroy or dissolve previously cemented deposits. The amount and nature of the erosional event(s) will be a function of the level of velocity of water in contact with the breccia, its chemistry, and the original surface area occupied by the breccia. Water-eroded breccias are evidenced, for example, by the deposits in Gua Monyet of west Timor, where phreatic erosional features dominate, such as rounded surfaces and undercutting of unconsolidated sediment (Fig. 6d). The records of Lene Hara and Laili demonstrate that chemical erosion of breccia is also probably common. In such instances, clasts including fossils may erode out and subsequently be incorporated into a lithified facies several times without actually undergoing any lateral transfer. Vertebrate assemblages preserved in such ways may therefore exhibit considerable time-averaging within a single breccia. Unravelling the depositional history of such a breccia is not possible without an extensive dating program and detailed petrological analyses. Furthermore, developing a precise understanding of the depositional history of the vertebrate material within such deposits may be impossible where they date to beyond the radiocarbon window, due to the limitations of direct dating techniques available beyond $\sim 50$ ka (i.e., U-Th, electron spin resonance (ESR)). 
Finally, where a deposit has undergone limited lateral cementation as a result of the particular water flow regime acting on the sediments, such as the anthropogenic-accumulated breccias described above, erosional events have the potential to remove the entirety of a deposit. Complete loss of material will be less likely for diamectite and turbidite breccias, where the original deposit is likely to be thick and extensive, probably filling several passages, such that localised erosional events would only remove parts of that deposit. The preservation of breccia within sheltered, side chambers often observed in the Sumatran caves likely demonstrates this phenomenon.

\section{Implications}

The preservation of vertebrate remains requires the presence of a bone accumulating agent. That human agency emerges as the most important factor in the preservation of faunal material in many caves in Island Southeast Asia has important implications for understanding extinction dynamics of vertebrates on small isolated islands. Given their geology, biogeographical location, and most importantly, records of human colonisation, the likelihood of any pre-human records on any of these islands is very small. Therefore, in the absence of fluvial or lacustrine vertebrate-bearing deposits, we are unlikely to ever know anything about colonisations, speciation, and extinctions of island endemics prior to human arrival for many of the islands in Wallacea, especially if such processes played out entirely before human colonisation. That such events occurred is evidenced by the few records we do have of prehuman faunal communities (e.g., Timor: Louys et al., 2016). Understanding these processes is critical for establishing baselines of natural faunal change through time (Steadman, 2006; Hadly \& Barnosky, 2009; Willis et al., 2010; Bennington \& Aronson, 2012), and for determining whether human arrival on islands precipitated extinctions at a rate higher than natural background levels. Furthermore, even when such processes overlap with human colonisation, any extinct faunal remains preserved in archaeological deposits will be biased representations of original faunal communities. If humans did not process the extinct animal in question, or if such a taxon is not in a commensal relationship with people, then the likelihood that they will be preserved in archaeological deposits is very small. Furthermore, because the first snapshot we are likely to have of an island's prehistory is archaeological, establishing which species are endemic and which are introduced by people might also be highly problematic. This has implications for the nascent field of conservation palaeobiology. This field is predicated on using the fossil record to inform conservation decisions. For example, information from the fossil record can be used to establish whether or not a species might be considered endemic to a particular region, and thus, is important for conservation (Coffey et al., 2011; Dietl et al., 2014). In Island Southeast Asia this is particularly relevant to understanding the origins and dispersals of pest rodents, many of which have endemic ranges in the region worth preserving.
For example, the Pacific rat Rattus exulans is endemic to Flores, but is considered a pest in many other regions (Thomson et al., 2014). In addition to Flores, it is found throughout the surrounding islands of Nusa Tenggara. Whether dispersals into these islands were natural or anthropogenic has important conservation implications. However, without fossil records predating human arrival, driving factors surrounding its dispersal will likely remain uncertain (e.g., Carden et al., 2012; Giovas et al., 2012).

General formation processes of vertebrate-bearing breccia in caves are still poorly understood and we agree with some authors who advocate a more detailed and nuanced examination of fossil deposits in the region (e.g., Zeitoun et al., 2015, 2016). In part, this limited understanding is due to the idiosyncrasies of each cave system, the complex speleogenesis events therein, and the limitations of analytical techniques available to researchers. Our observations indicate that considerable reworking of a breccia through at least one, and possible several, cycles is possible, resulting in time-averaged deposits that could span several hundreds of thousands of years. While directly dated flowstones may bracket a deposit, this bracket could be in the order of hundreds of thousands of years, as demonstrated by the unconsolidated natural deposits of Matja Kuru TD, where flowstone at the base is dated to $\sim 200 \mathrm{ka}$ and the speleothem crust at the top is dated to $\sim 10 \mathrm{ka}$. Furthermore, this site demonstrates that capping flowstones may not always provide a minimum age; for example, if the underlying deposits have been removed, creating a false floor, and refilled again. Direct dating of individual fossils in a breccia may not provide any better resolution. If attempted through U-Th dating, such an analysis will only provide a minimum age for one specimen, and if significantly different ${ }^{230} \mathrm{Th}$ ages are derived for many fossils in a deposit, then it will not be possible to determine if a breccia is minimally time-averaged or not. For example, two pig teeth dated using U-Th from Breccia 5 of Lang Trang, Vietnam produced ${ }^{230} \mathrm{Th}$ ages from the dentine of $>500 \mathrm{ka}$ and $\sim 120 \mathrm{ka}$ (Wood et al., 2016). If both are interpreted as reliable minimum ages, it is impossible on the basis of this data alone to determine if this deposit represents a single breccia event $>500 \mathrm{ka}$, or if multiple phases of dissolution and cementation produced a highly timeaveraged deposit. Direct ESR dating of teeth may resolve these issues; however, teeth with complex U-uptake histories may not be able to ever produce direct ages (Grün et al., 2014). In this regard, strident calls for more direct dating of fossils (e.g., Zeitoun et al., 2015: 414, 421; Zeitoun et al., 2016: 15, 22) is unlikely to be the panacea that these authors would like it to be, as direct dating in isolation may not provide all of the information required to understand the depositional history, time-averaging, or habitat-averaging characteristics of a deposit, particularly for those deposits dating to beyond the radiocarbon threshold. Instead, geochronological data will need to be complemented by, where appropriate, geochemical, petrographic, mineralogical, palynological, tomographic, and taphonomic evidence 
in order to fully elucidate the depositional histories of assemblages (cf. Hunt et al., 2015).

Even with such analyses, it is likely that breccia deposits in Southeast Asia, which currently constitute the bulk of the region's palaeontological record, may never provide the chronological resolution yearned for by some researchers, especially at the scale of 'climatic fluctuations' or marine isotope stages (cf. Lenoble et al., 2006; Zeitoun et al., 2015, 2016). Because of this, it has been implied that such deposits belong in the waste bin of palaeontology, as they add little value to palaeoecology or biogeography. Putting aside the fact that concentrating on a single climatic period ignores biologically important niche flexibility in a species, we argue that this perception of the value of an assemblage needs to be re-evaluated, and specifically viewed through a different temporal scale. While questions regarding interactions between humans and other vertebrates may require data at the precision of major glacial periods (i.e., scales of thousands of years), or even higher, research questions regarding palaeobiological processes or evolution play out over scales of many hundreds of thousands to millions of years. For such questions, data from Southeast Asian assemblages (breccia or otherwise), even if time-averaged, still prove invaluable for formulating testable hypotheses and useful discussions.

Like all deposit types, the potential of a cave to preserve locally occurring vertebrates autochthonously can also bias a region's fossil record, in terms of both species representation and perceptions of past biogeographic distributions (Yass \& George, 2010). In Southeast Asia, such biases are likely to be acute, as for many regions fossil records are, at present, solely or largely represented only by cave deposits. Currently, examination of the regional nature of this bias may be possible using the fossil records of Java and China. However, given the difficulties of finding non-cave sites in densely vegetated, tropical environments such as Southeast Asia (e.g., Morley, 2016), it is perhaps unlikely that this bias can ever be properly evaluated for many islands or regions in low latitudes.

\section{CONCLUSIONS}

While geological factors clearly have a strong impact on the likelihood of preservation of vertebrates in Southeast Asian caves, biotic processes are the ultimate drivers in accumulation. It is these processes that provide the faunal material that may then be subjected to long term geological preservation. Biotic processes in Southeast Asia are strongly dictated by biogeographical constraints, with owls and humans emerging as the dominant bone accumulating agent in many of the small, isolated islands of Wallacea. In the larger, continental regions of Southeast Asia, other mammalian accumulators, most notably porcupines (but probably extending to hyenas and other trogloxene carnivores outside of Sumatra) appear to be the dominant bone accumulators. The longterm preservation of vertebrate remains in caves is highly dependent on geology, being almost completely restricted to cemented deposits in limestone caves, but interestingly does not appear do have any relation to the age of the cave system or the host limestone, as evidenced by several very young breccias recorded in the region. Multiple cementation and dissolution events can be recorded within a single breccia without significant lateral movement of fossils, indicating that depositional histories for individual breccias are potentially highly complex and may result in significant time- or habitat-averaging of fossils. In instances where such events extend beyond radiocarbon dating thresholds, a comprehensive dating program in conjunction with detailed micromorphological, taphonomic, tomographic, and speleological analysis will be the only means of unravelling complex breccia formation histories.

\section{ACKNOWLEDGEMENTS}

We acknowledge the generous funding provided by ARC Laureate Project FL120100156 (to S. O'Connor), ARC Discovery Project DP120101752 (to G.J. Price), Leaky Foundation Grant "Palaeontological and archaeological investigations of Pleistocene cave deposits from Sumatra”, and a Research School of Asia and the Pacific Grant Development Support Grant (to J. Louys). Funding for tomographic analysis was provided by Bragg Institute Neutron Proposal P4561. Julien Louys is supported by ARC Future Fellowship Project FT160100450. We thank the students at Universitas Gadjah Mada and staff at Balai Arkeologi for their assistance during fieldwork in Talaud, Sangihe, Alor, and Pantar, and Christian Reepmeyer and Felicitas Hopf for their invaluable contributions to fieldwork in Talaud and Sangihe. Fieldwork in Timor was undertaken with the assistance of Cecilia Assis and the Ministerio da Educacao, Cultura, Juventude e Desporto de Timor-Leste. We thank R. Lee Lyman, David S. Gillieson, and an anonymous reviewer whose insightful comments helped improve this manuscript.

\section{REFERENCES}

Abbott M.J. \& Chamalaun F.H., 1981 - Geochronology of some Banda Arc volcanics. The geology and tectonics of Eastern Indonesia, 2: 253-268.

Aplin K.P. \& Helgen K.M., 2010 - Quaternary murid rodents of Timor Part I: new material of Coryphomys buehleri Schaub, 1937, and description of a second species of the genus. Bulletin of the American Museum of Natural History, 341: 1-80.

https://doi.org/10.1206/692.1

Bacon A.M., Demeter F., Schuster M., Long V.T., Thuy N.K., Antoine P.-O., Sen S., Huu Nga H. \& Huong N.M., 2004 - The Pleistocene Ma U'Oi cave, northern Vietnam: palaeontology, sedimentology and palaeoenvironments. Geobios, 37: 305-314. https://doi.org/10.1016/i.geobios.2003.03.010

Duringer P., Antoine P.O., Thuy N.K., Mai T.B., Huong N.T.M., Dodo Y., Matsumura H., Schuster M. \& Anezaki T., 2006 - New palaeontological assemblage, sedimentological and chronological data from the Pleistocene Ma U'Oi cave (northern Vietnam). Palaeogeography, Palaeoclimatology, Palaeoecology, 230: 280-298.

https://doi.org/10.1016/j.palaeo.2005.07.023 
Bacon A.M., Demeter F., Duringer P., Helm C., Bano M., Long V.T., Thuy N.T.K., Antoine P.-O., Mai B.T., Huong N.T.M. \& Dodo Y., 2008 - The Late Pleistocene Duoi U'Oi cave in northern Vietnam: palaeontology, sedimentology, taphonomy and palaeoenvironments. Quaternary Science Reviews, 27: 1627-1654. https://doi.org/10.1016/j.quascirev.2008.04.017

Bacon A.M., Westaway K., Antoine P.O., Duringer P., Blin A., Demeter F., Ponche J.-L., Zhao J.-X., Barnes L.M., Sayavonkhamdy T., Thuy N.T.L., Long V.T., Edoumba E. \& Shackleford L., 2015 - Late Pleistocene mammalian assemblages of Southeast Asia: new dating, mortality profiles and evolution of the predator-prey relationships in an environmental context. Palaeogeography, Palaeoclimatology, Palaeoecology, 422: 101-127. https://doi.org/10.1016/j.palaeo.2015.01.011

Barker G., (Ed.). 2013 - Rainforest foraging and farming in Island Southeast Asia. McDonald Institute for Archaeological Research, Cambridge, 464 p.

Bennington J.B. \& Aronson M.F., 2012 - Reconciling scale in paleontological and neontological data: dimensions of time, space, and taxonomy. In: Louys J. (Ed.), Paleontology in ecology and conservation. Springer Berlin Heidelberg, pp. 39-67. https://doi.org/10.1007/978-3-642-25038-54 4

Bountalis A.C. \& Kuhn B.F., 2014 - Cave usage by multiple taphonomic agents: issues towards interpreting the fossil bearing cave deposits in South Africa. American Journal of Zoological Research, 2: 55-61. https://doi.org/10.12691/ajzr-2-4-1

Brain C.K., 1981 - The hunters or the hunted? University of Chicago Press, Chicago, 376 p.

Carden R.F., McDevitt A.D., Zachos F.E., Woodman P.C., O'Toole P., Rose H., Monaghan N.T., Campana M.G., Bradley D.G. \& Edwards C.J., 2012 - Phylogeographic, ancient DNA, fossil and morphometric analyses reveal ancient and modern introductions of a large mammal: the complex case of red deer (Cervus elaphus) in Ireland. Quaternary Science Reviews, 42: 74-84. https://doi.org/10.1016/j.quascirev.2012.02.012

Chafetz H.S., Wilkinson B.H. \& Love K.M., 1985 Morphology and composition of non-marine carbonate cements in near-surface settings. In: Schneidermann N. \& Harris P.M. (Eds.), Special Publications of SEPM. Carbonate cements (SP36), pp. 337-347. https://doi.org/10.2110/pec.85.36.0337

Chamalaun F.H. \& Grady A.E., 1978 - The tectonic evolution of Timor: a new model and its implications for petroleum exploration. Australian Petroleum Exploration Association Journal, 18: 102-108.

Cheng H., Edwards R.L., Hoff J., Gallup C.D., Richards D.A. \& Asmerom Y., 2000 - The half-lives of uranium-234 and thorium-230. Chemical Geology, 169: 17-33. https://doi.org/10.1016/S0009-2541(99)00157-6

Clark T.R., Zhao J., Roff G., Feng Y., Done T.J., Nothdurft L.D. \& Pandolfi J.M., 2014 - Discerning the timing and cause of historical mortality events in modern Porites from the Great Barrier Reef. Geochimica et Cosmochimica Acta, 138: 57-80.

https://doi.org/10.1016/j.gca.2014.04.022

Coffey E.E.D, Froyd C.A. \& Willis K.J., 2011 - When is an invasive not an invasive? Macrofossil evidence of doubtful native plant species in the Gal'apagos Islands. Ecology, 92: 805-812.

https://doi.org/10.1890/10-1290.1

Cox N.L., 2009 - Variable uplift from Quaternary folding along the northern coast of East Timor, based on U-series age determinations of coral terraces. Unpublished MS thesis, Brigham Young University, $142 \mathrm{p}$.
Demeter F., Shackelford L.L., Bacon A.M., Duringer P., Westaway K., Sayavongkhamdy T., Braga J., Sichanthongtip, Khamdalavong P., Ponche J-L., Wang H., Lundstrom C., Patole-Edoumba E. \& Karpoff A-M., 2012 - Anatomically modern human in Southeast Asia (Laos) by $46 \mathrm{ka}$. Proceedings of the National Academy of Sciences, 109: 14375-14380.

https://doi.org/10.1073/pnas.1208104109

Dietl G.P., Kidwell S.M., Brenner M., Burney D.A., Flessa K.W., Jackson S.T. \& Koch P.L., 2015 - Conservation paleobiology: Leveraging knowledge of the past to inform conservation and restoration. Annual Review of Earth and Planetary Sciences, 43: 79-103.

https://doi.org/10.1146/annurev-earth-040610-133349

Drawhorn G.M., 1994 - The systematics and paleodemography of fossil orangutans. Unpublished PhD Thesis, University of California, 232 p.

Dreybrodt W., 2004 - Carbonate minerals: precipitation. In: Gunn J. (Ed.), Encyclopedia of caves and karst science. Taylor and Francis, New York, p. 187-188.

Dubois E., 1891 - Voorloopig bericht omtrent het onderzoek naar de Pleistocene en tertiaire Vertebraten-Fauna van Sumatra en Java, gedurende het jaar 1890. Natuurkundig Tijdschrift voor Nederlandsch Indie, 51: 93-100.

Duringer P., Bacon A.M., Sayavongkhamdy T. \& Nguyen T.K.T., 2012 - Karst development, breccias history, and mammalian assemblages in Southeast Asia: a brief review. Comptes Rendus Palevol, 11: 133-157.

https://doi.org/10.1016/j.crpv.2011.07.003

Fairchild I.J. \& Baker A., 2012 - Speleothem science: from process to past environments. John Wiley \& Sons, Hoboken, $450 \mathrm{p}$. https://doi.org/10.1002/9781444361094

Fallon S.J., Fifield L.K. \& Chappell J.M., 2010 - The next chapter in radiocarbon dating at the Australian National University: status report on the single stage AMS. Nuclear Instruments and Methods in Physics Research, Section B: Beam Interactions with Materials and Atoms, 268: 898-901. https://doi.org/10.1016/j.nimb.2009.10.059

Farrand W.R., 2001 - Sediments and stratigraphy in rockshelters and caves: a personal perspective on principles and pragmatics. Geoarchaeology, 16: 537-557. https://doi.org/10.1002/gea.1004

Farrant A., 2004 - Paleoenvironment: clastic cave sediments. In: Gunn J. (Ed.). Encyclopedia of caves and karst science. Taylor and Francis, New York, p. 553-555.

Gagan M.K., Ayliffe L.K., Smith G.K., Hellstrom J.C., Scott-Gagan H., Drysdale R.N., Anderson N., Suwargadi B., Aplin K., Zhao J.-X., Groves C.W., Hantoro W. \& Djubiantono T., 2015 - Geoarchaeological finds below Liang Bua (Flores, Indonesia): a split-level cave system for Homo floresiensis? Palaeogeography, Palaeoclimatology, Palaeoecology, 440: 533-550. https://doi.org/10.1016/j.palaeo.2015.09.021

Garbe U., Randall T. \& Hughes C., 2011 - The new neutron radiography/tomography/imaging station DINGO at OPAL. Nuclear Instruments and Methods in Physics Research Section A: Accelerators, Spectrometers, Detectors and Associated Equipment, 651: 42-46. https://doi.org/10.1016/j.nima.2011.02.017

Gilbertson D., McLaren S., Stephens M., Hunt C., Rose J., Dykes A., Grattan J., Bird M., Lewis H., Kealhofer L., Richard Mani B., Daly D., Patrick R., Rushworth G., Pyatt B., Thompson G., Piper P. \& Rabett R., 2013. - The cave entrance sequences and environmental change. In: Barker B. (Ed.), Rainforest foraging and farming in Island Southeast Asia. McDonald Institute for Archaeological Research, Cambridge, p. 71-134. 
Gillieson D., 1986 - Cave sedimentation in the New Guinea highlands. Earth Surface Processes and Landforms, 11: $533-543$. https://doi.org/10.1002/esp.3290110508

Gillieson D., 2004 - Sediments: allochthonous clastic. In: Gunn J. (Ed.), Encyclopedia of caves and karst science. Taylor and Francis, New York, p. 633-634.

Giovas C.M., LeFebvre M. \& Fitzpatrick S.M., 2012 New records for prehistoric introduction of Neotropical mammals to the West Indies: evidence from Carriacou, Lesser Antilles. Journal of Biogeography, 39: 476-487.

Glover I., 1979 - The effects of sink action on archaeological deposits in caves: an Indonesian example. World Archaeology, 10: 302-317.

Glover, I., 1986 - Archaeology in Eastern Timor, 196667. Terra Australis, 11. Department of Prehistory, Australian National University, 241 p.

Grün R., Eggins S., Kinsley L., Moseley H. \& Sambridge M., 2014 - Laser ablation U-series analysis of fossil bones and teeth. Palaeogeography, Palaeoclimatology, Palaeoecology, 416: 150-167.

Hadly E.A. \& Barnosky A.D., 2009 - Vertebrate fossils and the future of conservation biology. In: Dietl G.P. \& Flessa K.W. (Eds.), Conservation paleobiology: using the past to manage for the future, Vol. 15, The palaeontology society papers. Palaeontological Society, Lubbock, p. 39-59.

Hall R., 2002 - Cenozoic geological and plate tectonic evolution of SE Asia and the SW Pacific: computerbased reconstructions, model and animations. Journal of Asian Earth Sciences, 20: 353-431.

Hamilton W., 1979. - Tectonics of the Indonesian region. US Geological Survey Professional Paper 1078, 345 p.

Hantoro W.S., Pirazzoli P.A., Jouannic C., Faure H., Hoang C.T., Radtke U., Causse C., Borel Best M., Lafont R., Bieda S. \& Lambeck K., 1994 - Quaternary uplifted coral reef terraces on Alor Island, East Indonesia. Coral Reefs, 13: 215-223.

Harris R.A., 1991 - Temporal distribution of strain in the active Banda orogen: a reconciliation of rival hypotheses. Journal of Southeast Asian Earth Sciences, 6: 373-386.

Hawkins S., Samper Carro S.C., Louys J., Aplin K. \& O'Connor S., 2017 - Human palaeoecological interactions and owl roosting at Tron Bon Lei, Alor Island, eastern Indonesia. Journal of Coastal and Island Archaeology (in press).

https://doi.org/10.1080/15564894.2017.1285834

Hill C.A. \& Forti P., 2004 - Minerals in caves. In: Gunn J. (Ed.). Encyclopedia of caves and karst science. Taylor and Francis, New York, p. 511-514.

Hocknull S.A., Piper P.J., van den Bergh G.D., Due R.A., Morwood M.J. \& Kurniawan I., 2009 - Dragon's paradise lost: palaeobiogeography, evolution and extinction of the largest-ever terrestrial lizards (Varanidae). PLoS One, 4: e7241.

https://doi.org/10.1371/journal.pone.0007241

Hooijer D.A., 1971 - A giant land tortoise, Geochelone atlas (Falconer \& Caytley), from the Pleistocene of Timor I and II. Proceedings Koninklijk Nederlandsch Akadamie van Wetenschappen Series B, 74: 504-525.

Hunt C.O., Gilbertson D.D., Hill E.A. \& Simpson D., 2015 - Sedimentation, re-sedimentation and chronologies in archaeologically-important caves: problems and prospects. Journal of Archaeological Science, 56: 109-116. https://doi.org/10.1016/j.jas.2015.02.030

Hutchison C.S., 1989 - Geological evolution of South-east Asia (Vol. 13) Oxford, Clarendon Press, 368 p.

Hutchison C.S., 1993 - Gondwanaland and Cathaysian blocks, Palaeotethys sutures and Cenozoic tectonics in South-East Asia. Geologisches Rundschau, 82: 388-405.
Hutchinson C.S., 2005 - The geological framework. In: Gupta A. (Ed.), The physical geography of Southeast Asia. Oxford University Press, Oxford, p. 3-23.

Jass C.N. \& George C.O., 2010 - An assessment of the contribution of fossil cave deposits to the Quaternary paleontological record. Quaternary International, 217: 105-116.

https://doi.org/10.1016/j.quaint.2009.11.008

Kealy S., Louys J. \& O'Connor S., 2017 - Reconstructing palaeogeography and inter-island visibility in the Wallacean Archipelago during the likely period of Sahul colonisation, 65-45,000 years ago. Archaeological Prospection (in press).

https://doi.org/10.1002/arp.1570

Kitchener D.J., Aplin K.P. \& Boeadi A., 1991 - A new species of Rattus from Gunung Mutis, South West Timor Island, Indonesia. Records of the Western Australian Museum, 15: 445-465.

Kitchener D.J., Hisheh S., Schmitt L.H. \& Suyanto A., 1994 - Shrews (Soricidae: Crocidura) from the Lesser Sunda islands and southeast Maluku, eastern Indonesia. Australian Mammalogy, 17: 7-17.

Koch A., Arida E., Riyanto W. \& Böhme W., 2009a Islands between the realms: a revised checklist of the herpetofauna of the Talaud Archipelago, Indonesia, with a discussion about its biogeographic affinities. Bonner Zoologische Beiträge, 56:107-129.

Koch A., Arida E., Schmitz A., Böhme W. \& Ziegler T., 2009b - Refining the polytypic species concept of mangrove monitors (Squamata: Varanus indicus group): a new cryptic species from the Talaud Islands, Indonesia, reveals the underestimated diversity of Indo-Australian monitor lizards. Australian Journal of Zoology, 57: 29-40.

https://doi.org/10.1071/ZO08072

Langley M.C. \& O'Connor S., 2016 - An enduring shell artefact tradition from Timor-Leste: Oliva bead production from the Pleistocene to Late Holocene at Jerimalai, Lene Hara, and Matja Kuru 1 and 2. PloS One, 11: e0161071.

https://doi.org/10.1371/journal.pone.0161071

Lanting J.N. \& van der Plicht J., 1998 - Reservoir effect and apparent ${ }^{14} \mathrm{C}$-ages. Journal of Irish Archaeology, 9: 151-165.

Latham A.G., Schwarcz H.P., 1992 - Carbonate and sulphate precipitates, In: Ivanovich M., Harmon R.S. (Eds.), Uranium-Series disequililbrium: application to earth, marine and environmental sciences ( $2^{\text {nd }}$ Edition). Oxford Scientific Publications, Oxford, p. 423-459.

Lenoble A., Zeitoun V., Laudet F., Seveau A. \& Doyasa T., 2006 - Natural processes involved in the formation of Pleistocene bone assemblages in continental SouthEast Asian caves: the case of the cave of the monk (Chiang Dao Wildlife Sanctuary, Thailand). In: 11th International Conference of the Eurasea. Siam Ratana Ltd, Chiang Mai, p. 41-50.

Leonard J.A., Tex R.J., Hawkins M.T., MuñozFuentes V., Thorington R. \& Maldonado J.E., 2015 - Phylogeography of vertebrates on the Sunda Shelf: a multi-species comparison. Journal of Biogeography, 42: 871-879.

https://doi.org/10.1111/jbi.12465

Liu W., Jin C.Z., Zhang Y.Q., Cai Y.J., Xing S., Wu, Cheng H., Edwards R.L., Pan W.-S., Qin D.-G., An Z.S., Trinkaus E. \& Wu X.-Z., 2010 - Human remains from Zhirendong, South China, and modern human emergence in East Asia. Proceedings of the National Academy of Sciences, 107: 19201-19206. https://doi.org/10.1073/pnas.1014386107 
Louys J., 2014 - The large terrestrial carnivore guild in Quaternary Southeast Asia. Quaternary Science Reviews, 96: 86-97. https://doi.org/10.1016/j.quascirev.2013.06.014

Louys J., Curnoe D. \& Tong H., 2007 - Characteristics of Pleistocene megafauna extinctions in Southeast Asia. Palaeogeography, Palaeoclimatology, Palaeoecology, 243: 152-173.

https://doi.org/10.1016/j.palaeo.2006.07.011

Louys J. \& Meijaard E., 2010 - Palaeoecology of Southeast Asian megafauna-bearing sites from the Pleistocene and a review of environmental changes in the region. Journal of Biogeography, 37: 1432-1449.

https://doi.org/10.1111/j.1365-2699.2010.02297.x

Louys J., Price G.J. \& O'Connor S., 2016 - Direct dating of Pleistocene stegodon from Timor Island, East Nusa Tenggara. PeerJ, 4: e1788.

https://doi.org/10.7717/peerj.1788

Louys J., Herrera M., Hawkins S., Aplin K., Reepmeyer C., Hopf F., Donnellan S.C., O'Connor S. \& Tanudirjo D.A. - Neolithic dispersal implications of murids from late Holocene archaeological and modern natural deposits in the Talaud Islands, northern Sulawesi. In: Bulbeck D., O'Connor S. \& Meyer J. (Eds.), The archaeology of Sulawesi. Terra Australis, ANU E Press, Canberra (in press).

Ludwig K.R., Simmons K.R., Szabo B.J., Winograd I.J., Landwehr J.M., Riggs A.C. \& Hoffman R.J., $1992-$ Mass-spectrometric ${ }^{230} \mathrm{Th}^{2}{ }^{234} \mathrm{U}-{ }^{238} \mathrm{U}$ dating of the Devils Hole calcite vein. Science, 258: 284-287. https://doi.org/10.1126/science.258.5080.284

Ludwig K.R., 2003 - User's manual for Isoplot/Ex version 3.0: a geochronological toolkit for Microsoft Excel. Berkeley Geochronology Centre, Berkeley.

Lyman R.L., 1994 - Vertebrate taphonomy. Cambridge University Press, Cambridge, 524 p. https://doi.org/10.1017/CBO9781139878302

McFarlane D.A., 2013 - Limestone caves and the Quaternary record of terrestrial tetrapods on islands. Journal of the Geological Society, 170: 535-538. https://doi.org/10.1144/jgs2012-015

McGregor H.V. Gagan M.K. McCulloch M.T. Hodge E. \& Mortimer G., 2008 - Mid-Holocene variability in the marine $14 C$ reservoir age for northern coastal Papua New Guinea. Quaternary Geochronology, 3: 213-225. https://doi.org/10.1016/j.quageo.2007.11.002

Mijares A.S., Détriot F., Piper P., Grün R., Bellwood P., Aubert M., Champion G., Cuevas N., De Leon A. \& Dizon E., 2010 - New evidence for a 67,000-year-old human presence at Callao Cave, Luzon, Philippines. Journal of Human Evolution, 59: 123-132. https://doi.org/10.1016/j.jhevol.2010.04.008

Morley M.W., 2016 - The geoarchaeology of hominin dispersals to and from tropical Southeast Asia: A review and prognosis. Journal of Archaeological Science, 77: 78-93.

https://doi.org/10.1016/j.jas.2016.07.009

Moore G.F., Kadarisman D., Evans C.A. \& Hawkins J.W., 1981 - Geology of the Talaud Islands, Molucca Sea collision zone, northeast Indonesia. Journal of Structural Geology, 3: 467-475.

https://doi.org/10.1016/0191-8141(81)90046-8

Morwood M.J., Soejono R.P., Roberts R.G., Sutikna T., Turney C.S., Westaway K.E., Rink W.J., Zhao X., van den Bergh G., Due R.A., Hobbs D.R., Moore M.W., Bird M.I. \& Fifield L.K., 2004 -Archaeology and age of a new hominin from Flores in eastern Indonesia. Nature, 431: $1087-1091$.

https://doi.org/10.1038/nature02956
Morrice M.G., Jezek P.A., Gill J.B., Whitford D.J. \& Monoarfa M., 1983 - An introduction to the Sangihe arc: volcanism and accompanying arc-arc collision in the Molucca Sea, Indonesia. Journal of Volcanology and Geothermal Research, 19:135-165.

https://doi.org/10.1016/0377-0273(83)90129-4

Mylroie J.E. \& Carew J.L., 1990 - The flank margin model for dissolution cave development in carbonate platforms. Earth Surface Processes and Landforms, 15: 413-424. https://doi.org/10.1002/esp.3290150505

Mylroie J.E. \& Mylroie J.R., 2009 - Caves as sea level and uplift indicators, Kangaroo Island, South Australia. Journal of Cave and Karst Studies, 71: 32-47.

Nater A., Greminger M.P., Arora N., Schaik C.P., Goossens B., Singleton I., Verschoor E., Warren K.S. \& Krützen M., 2015 - Reconstructing the demographic history of orang-utans using Approximate Bayesian Computation. Molecular Ecology, 24: 310-327.

https://doi.org/10.1111/mec.13027

Nguyen N., Duffy B., Shulmeister J. \& Quigley M., 2013 - Rapid Pliocene uplift of Timor. Geology, 41: 179-182. https://doi.org/10.1130/G33420.1

O'Connor S. \& Aplin K., 2007 - A matter of balance: an overview of Pleistocene occupation history and the impact of the Last Glacial Phase in East Timor and the Aru Islands, eastern Indonesia. Archaeology in Oceania, 42: 82-90.

https://doi.org/10.1002/j.1834-4453.2007.tb00021.x

O’Connor S., Barham A., Aplin K. \& Maloney T., 2016 - Cave stratigraphies and cave breccias: Implications for sediment accumulation and removal models and interpreting the record of human occupation. Journal of Archaeological Science, 77: 143-159.

https://doi.org/10.1016/j.jas.2016.05.002

O’Connor S., Barham A., Spriggs M., Veth P., Aplin K. $\&$ St Pierre E., 2010 - Cave archaeology and sampling issues in the tropics: A case study from Lene Hara Cave, a 42,000 year old occupation site in East Timor, Island Southeast Asia. Australian Archaeology, 71: 29-40. https://doi.org/10.1080/03122417.2010.11689382

O’Connor S., Louys J., Kealy S. \& Mahirta, 2015 - First record of painted rock art in Kupang, West Timor, Indonesia and the origins and distribution of the Austronesian Painting Tradition. Rock Art Research, 32: 193-201.

O'Connor S., Ono R. \& Clarkson C., 2011 - Pelagic fishing at 42,000 years before the present and the maritime skills of modern humans. Science, 334: 1117-1121. https://doi.org/10.1126/science. 1207703

O'Connor S., Mahirta, Samper Carro S.C., Hawkins S., Kealy S., Louys J. \& Wood R. - Fishing in life and death: Pleistocene fish-hooks from a burial context in Alor Island, Indonesia. Antiquity (in press).

O'Connor S., Spriggs M. \& Veth P., 2002 - Excavation at Lene Hara Cave establishes occupation in East Timor at least 30,000-35,000 years ago. Antiquity, 76: 45-50. https://doi.org/10.1017/S0003598X0008978X

Oktaviana A.A., Bulbeck D., O'Connor S., Hakim B., Wibowo U.P. \& St Pierre E., 2016 - Hand stencils with and without narrowed fingers at two new rock art sites in Sulawesi, Indonesia. Rock Art Research: The Journal of the Australian Rock Art Research Association (AURA), 33: 32-48.

O’Regan H.J., Kuman K. \& Clarke R.J., 2011 - The likely accumulators of bones: five cape porcupine den assemblages and the role of porcupines in the postmember 6 infill at Sterkfontein, South Africa. Journal of Taphonomy, 9: 69-87. 
Pike A.W.G., Hedges R.E.M. \& van Calsteren P., $2002-$ $U$-series dating of bone using the diffusion-adsorption model. Geochimica et Cosmochimica Acta, 66: 42734286. https://doi.org/10.1016/S0016-7037(02)00997-3

Price G.J., Louys J., Cramb J., Feng Y.-x., Zhao J.-x., Hocknull S.A., Webb G.E., Nguyen A.D. \& JoannesBoyau R., 2015 - Temporal overlap of humans and giant lizards (Varanidae; Squamata) in Pleistocene Australia. Quaternary Science Reviews, 125: 98-105. https://doi.org/10.1016/j.quascirev.2015.08.013

Price G.J., Feng Y.-x., Zhao J.-x. \& Webb G.E., 2013 Direct $U-T h$ dating of vertebrate fossils with minimum sampling destruction and application to museum specimens. Quaternary Geochronology, 18: 1-8. https://doi.org/10.1016/j.quageo.2013.07.003

Price G.J., Zhao J.-x., Feng Y.-x. \& Hocknull S.A., 2009a - New records of Plio-Pleistocene koalas from Australia: palaeoecological and taxonomic implications. Records of the Australian Museum, 61: 39-48. https://doi.org/10.3853/j.0067-1975.61.2009.1518

Price G.J., Zhao J.-x., Feng Y.-x. \& Hocknull S.A., 2009b - New U/Th ages for Pleistocene megafauna deposits of southeastern Queensland, Australia. Journal of Asian Earth Sciences, 34: 190-197.

https://doi.org/10.1016/j.jseaes.2008.04.008

Ramsey C.B., 2009 - Bayesian analysis of radiocarbon dates. Radiocarbon, 51: 337-360.

https://doi.org/10.1017/S0033822200033865

Reimer P.J., Bard E., Bayliss A., Beck J.W., Blackwell P.G., Bronk Ramsey C., Buck C.E., Cheng H., Edwards R.L., Friedrich M., Grootes P.M., Guilderson T.P., Haflidason H., Hajdas I., Hatté C., Heaton T.J., Hoffmann D.L., Hogg A.G., Hughen K.A., Kaiser K.F., Kromer B., Manning S.W., Niu M., Reimer R.W., Richards D.A., Scott E.M., Southon J.R., Staff R.A., Turney C.S.M. \& van der Plicht J., 2013 - IntCal13 and Marine 13 radiocarbon age calibration curves $0-50,000$ years cal BP. Radiocarbon, 55: 1869-1887.

https://doi.org/10.2458/azu js rc.55.16947

Riley J., 2002 - Mammals on the Sangihe and Talaud Islands, Indonesia, and the impact of hunting and habitat loss. Oryx, 36: 288-296.

https://doi.org/10.1017/S0030605302000510

Sambridge M., Grün R. \& Eggins S., 2012 - U-series dating of bone in an open system: the diffusionadsorption-decay model. Quaternary Geochronology, 9: 42-53.

https://doi.org/10.1016/j.quageo.2012.02.010

Samper Carro S.C., O'Connor S., Louys J., Hawkins S. \& Mahirta, 2016 - Human maritime subsistence strategies in the Lesser Sunda Islands during the terminal Pleistocene-early Holocene: new evidence from Alor, Indonesia. Quaternary International, 416: 64-79. https://doi.org/10.1016/j.quaint.2015.07.068

Shepherd C.R., 2006 - The bird trade in Medan, North Sumatra: an overview. Birding Asia, 5: 16-24.

Simms M.J., 1994 - Emplacement and preservation of vertebrates in caves and fissures. Zoological Journal of the Linnean Society, 112: 261-283.

https://doi.org/10.1111/j.1096-3642.1994.tb00320.x

Shahack-Gross R., Ayalon A., Goldberg P., Goren Y., Ofek B., Rabinovich R. \& Hovers E., 2008 -Formation processes of cemented features in karstic cave sites revealed using stable oxygen and carbon isotopic analyses: A case study at Middle Paleolithic Amud Cave, Israel. Geoarchaeology, 23: 43-62.

https://doi.org/10.1002/gea.20203

Shopov Y., 2004 - Sediments: biogenic. In: Gunn J. (Ed.), Encyclopedia of caves and karst science. Taylor and Francis, New York, p. 636-637.
Steadman D.W., 2006 - Extinction and biogeography of tropical Pacific birds. University of Chicago Press, 480 p.

St Pierre E., Zhao J.-x., Feng Y.-x. \& Reed E., 2012 $U$-series dating of soda straw stalactites from excavated deposits: method development and application to Blanche Cave, Naracoorte, South Australia. Journal of Archaeological Science, 39: 922-930.

https://doi.org/10.1016/j.jas.2011.10.027

Stuiver M. \& Braziunas T.F., 1993 - Modeling atmospheric ${ }^{14} \mathrm{C}$ influences and ${ }^{14} \mathrm{C}$ ages of marine samples to 10,000 $B C$. Radiocarbon, 35: 137-189.

https://doi.org/10.1017/S0033822200013874

Tate, Garrett W., McQuarrie N., Hinsbergen D., Bakker R., Harris R., Willett S., Reiners P., Fellin M.G., Ganerød M. \& Jan Zachariasse W., 2014 - Resolving spatial heterogeneities in exhumation and surface uplift in Timor-Leste: Constraints on deformation processes in young orogens. Tectonics, 33: 1089-1112.

https://doi.org/10.1002/2013TC003436

Thomson V., Aplin K.P., Cooper A., Hisheh S., Suzuki H., Maryanto I., Yap G. \& Donnellan S.C., 2014 - Molecular genetic evidence for the place of origin of the Pacific rat, Rattus exulans. PloS One, 9: e91356.

https://doi.org/10.1371/journal.pone.0091356

van Bemmelen R.W., 1949 - The Geology of Indonesia, vol. 1A. Government Printing Office, The Hague, 732 p.

Veth P.M., Spriggs M. \& O'Connor S., 2005 - Continuity in tropical cave use: examples from East Timor and the Aru Islands, Maluku. Asian Perspectives, 44: 180-192. https://doi.org/10.1353/asi.2005.0015

Villagran X.S., Strauss A., Miller C., Ligouis B. \& Oliveira R., 2016 - Buried in ashes: site formation processes at Lapa do Santo rockshelter, east-central Brazil. Journal of Archaeological Science, 77: 10-24.

https://doi.org/10.1016/j.jas.2016.07.008

Wallace A.R., 1864 - Bone caves in Borneo. Natural History Review, 4: 308-311.

Wood R.E., Arrizabalaga A., Camps M., Fallon S., IriarteChiapusso M.-J., Jones R., Maroto J., de la Rasilla M., Santamaría D., Soler J., Soler N., Villaluenga A. \& Higham T.F.G., 2014 - The chronology of the earliest Upper Palaeolithic in Northern Iberia: New insights from L'Arbreda, Labeko Koba and La Viña. Journal of Human Evolution 69: 91-109.

https://doi.org/10.1016/j.jhevol.2013.12.017

Wood R., Duval M., Huong N.T.M., Tuan N.A., Bacon A.M., Demeter F., Duringer P., Oxenham M. \& Piper P., 2016 - The effect of grain size on carbonate contaminant removal from tooth enamel: Towards an improved pretreatment for radiocarbon dating. Quaternary Geochronology, 36: 174-187.

Westaway K.E., Sutikna T., Saptomo W.E., Morwood M.J., Roberts R.G. \& Hobbs D.R., 2009 - Reconstructing the geomorphic history of Liang Bua, Flores, Indonesia: a stratigraphic interpretation of the occupational environment. Journal of Human Evolution, 57: 465-483. https://doi.org/10.1016/j.jhevol.2009.01.004

Westaway K.E., Louys J., Due Awe R., Morwood M.J., Price G.J., Zhao J.-x., Aubert M., Joannes-Boyau R., Smith T., Skinner M.M., Compton T., Bailey R.M., van den Bergh G.D., de Vos J., Pike A.W.G, Stringer C., Saptomo E.W., Rizal Y., Zaim J., Santoso W.D., Trihascaryo A., Kinsley L. \& Sulistyanto B., 2017 - An early modern human presence in Sumatra at 73,00063,000 years ago. Nature, 548: 322-325. https://doi.org/10.1038/nature23452

Whitten T., 2000 - The ecology of Sumatra (Vol. I). Periplus Editions, Hong Kong, 478 p. 
Willis K.J, Bailey R.M., Bhagwat S.A. \& Birks H.J.B. 2010 - Biodiversity baselines, thresholds and resilience: testing predictions and assumptions using palaeoecological data. Trends in Ecology and Evolution, 25: 583-591. https://doi.org/10.1016/j.tree.2010.07.006

Wilting A., Sollmann R., Meijaard E., Helgen K.M. \& Fickel J., 2012 - Mentawai's endemic, relictual fauna: is it evidence for Pleistocene extinctions on Sumatra? Journal of Biogeography, 39: 1608-1620. https://doi.org/10.1111/j.1365-2699.2012.02717.x

Zeitoun V., Chinnawut W., Debruyne R., Frère S. \& Auetrakulvit P., 2016 - A sustainable review of the Middle Pleistocene benchmark sites including the Ailuropoda-Stegodon faunal complex: the Proboscidean point of view. Quaternary International, 416: 12-26. https://doi.org/10.1016/j.quaint.2015.09.045
Zeitoun V., Chinnawut W., Debruyne R. \& Auetrakulvit P., 2015 - Assessing the occurrence of the Stegodon and Elephas in China and Southeast Asia during the Early Pleistocene. Bulletin de la Société Géologique de France, 6: 85-101.

Zhao J.X., Yu K.-f. \& Feng Y.-x., 2009 - High-precision ${ }^{238} U-{ }^{234} U-{ }^{230}$ Th disequilibrium dating of the recent past: a review. Quaternary Geochronology, 4: 423-433. https://doi.org/10.1016/j.quageo.2009.01.012

Zhou H., Zhao J., Qing W., Feng Y. \& Tang J., 2011 Speleothem-derived Asian summer monsoon variations in Central China, 54-46 ka. Journal of Quaternary Science, 26: 781-790.

https://doi.org/10.1002/jqs. 1506 